As RelaÇões Entre Religião e Estado.

NOTAS SOBRE AS EXPERIÊNCIAS NORTE-AMERICANA E BRASILEIRA. ${ }^{1}$

\author{
Ana Paula Gonçalves Pereira de Barcellos ${ }^{2}$ \\ Felipe Mendonça Terra ${ }^{3}$ \\ Filipe Seixo de Figueiredo ${ }^{4}$ \\ Paulo Vitor Torres da Matta ${ }^{5}$
}

\begin{abstract}
RESUMO
As relações entre religião e Estado a partir do direito constitucional contemporâneo no contexto brasileiro, norte-americano e no direito comparado. São estes os principais focos do presente artigo, que assume como premissa a relevante posição que ocupa o fenômeno religioso no Estado moderno e a sua indissociável dimensão pública. Dessa forma, serão vistos os diferentes modelos de relacionamento entre Estado e religião, afirmando-se quais as suas implicações com a democracia. Depois, serão apresentados alguns aspectos da liberdade religiosa no contexto norte-americano, como também no Brasil, a partir da análise histórica das Constituições brasileiras.
\end{abstract}

Palavras-chave: Liberdade religiosa. Constituição de 1988. Direitos fundamentais. Secularismo. Laicidade.

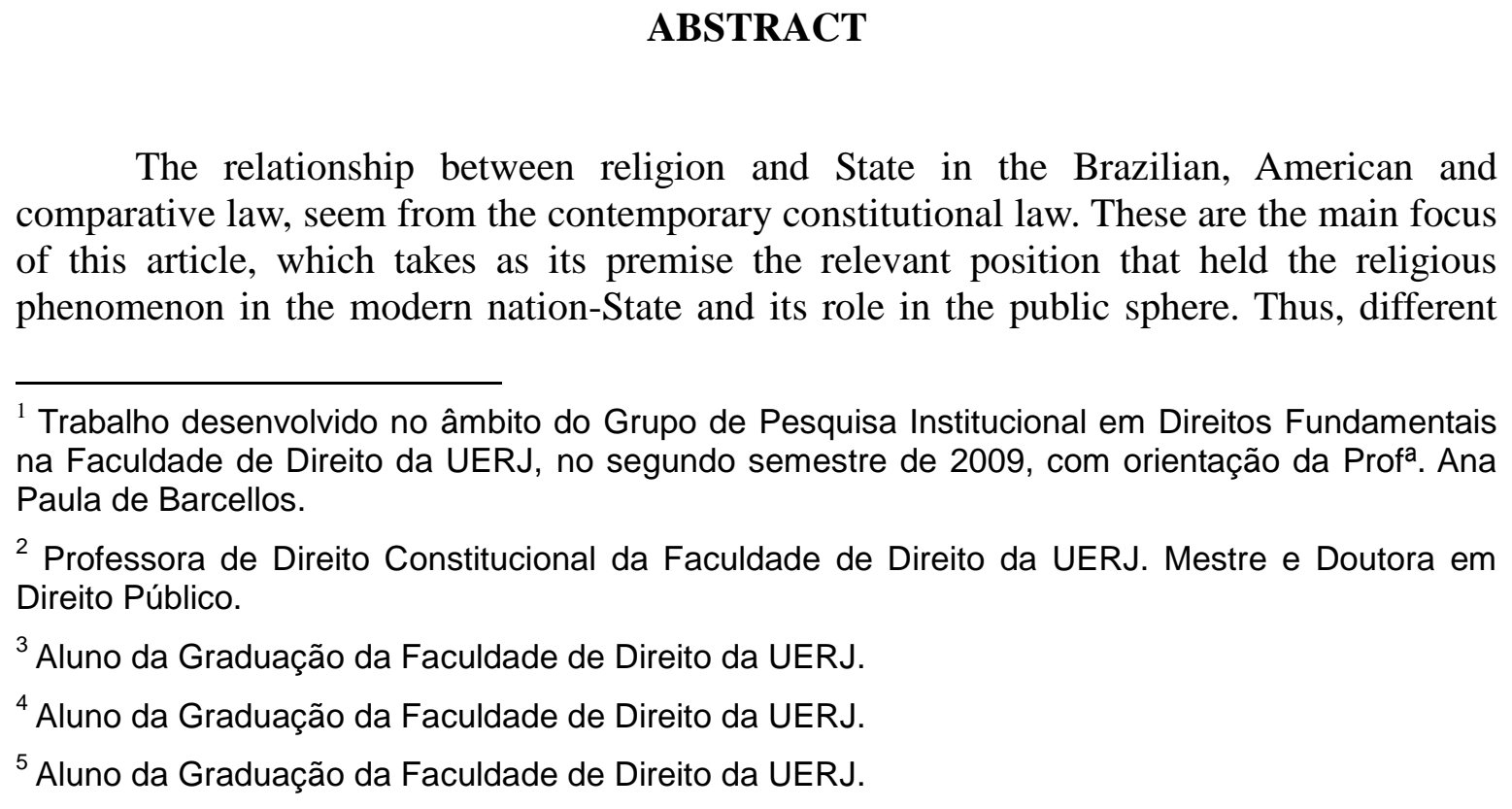

ABSTRACT

The relationship between religion and State in the Brazilian, American and comparative law, seem from the contemporary constitutional law. These are the main focus of this article, which takes as its premise the relevant position that held the religious phenomenon in the modern nation-State and its role in the public sphere. Thus, different

\footnotetext{
${ }^{1}$ Trabalho desenvolvido no âmbito do Grupo de Pesquisa Institucional em Direitos Fundamentais na Faculdade de Direito da UERJ, no segundo semestre de 2009, com orientação da Prof ${ }^{a}$. Ana Paula de Barcellos.

${ }^{2}$ Professora de Direito Constitucional da Faculdade de Direito da UERJ. Mestre e Doutora em Direito Público.

${ }^{3}$ Aluno da Graduação da Faculdade de Direito da UERJ.

${ }^{4}$ Aluno da Graduação da Faculdade de Direito da UERJ.

${ }^{5}$ Aluno da Graduação da Faculdade de Direito da UERJ.
} 
models of relationship between State and religion will be presented, stating what are their implications for the democracy. Then, will be introduced some aspects of the religious freedom in the North-American context and also in Brazil, from the historical analysis of its Constitutions.

Keywords: Religious freedom. Brazil's 1988 Constitution. Fundamental rights. Secularism. Establishment clause.

\section{As RelaÇões EnTre Religião e Estado.}

\section{Notas SObre As ExPERIÊNCIAS NORTE-AMERICANA E BRASILEIRA.}

\section{INTRODUÇÃO}

Nos tempos modernos, o fenômeno religioso, ao menos no mundo ocidental, está intimamente ligado à máxima cristã "dar a César o que é de César e a Deus o que é de Deus", que condiciona toda a relação entre o político e o religioso, o público e o privado. Há algum consenso que Estado e religião não devem imiscuir-se a ponto de integrarem uma mesma esfera. Ao mesmo tempo, quais os limites desejáveis de uma separação rígida entre política e religião? Quais arranjos entre esses dois fenômenos podem favorecer ou corromper a democracia e a liberdade?

A complexidade desta era de acentuado pluralismo certamente nos impede de lançar respostas unívocas ou pretensamente corretas a tais questões, o que não obsta, todavia, que apresentemos alguns dos principais modelos de relação entre o fenômeno religioso e o Estado e alguns dos aspectos mais intrigantes sobre a religião sob a ótica do constitucionalismo contemporâneo.

Tal averiguação jamais se dará sem necessidade: o modo como o poder político relaciona-se com as crenças mais íntimas dos indivíduos revela não só características históricas, sociológicas e políticas peculiares àquele Estado, como também determina os limites do seu exercício e a estruturação de uma esfera de intangibilidade estatal perante a consciência e a escolha pessoal de cada cidadão. Nesta toada, não poderá o Estado ignorar o fenômeno religioso como expressão pública de pertencimento de cada indivíduo à comunidade política; afinal, quem entenderá como legítimo um governo que não respeita a 
suas escolhas mais íntimas e pessoais ${ }^{6}$ ?

A frase bíblica a que aludidos acima, embora cunhada há mais de dois mil anos, como se sabe, demorou muito a surtir efeito como paradigma representativo da separação entre Estado e Igreja. De fato, tanto do monismo típico da Antiguidade, caracterizado pela total confusão entre religião e poder político, quanto do teocentrismo do período medieval, exsurgia a dificuldade de delimitação entre tais esferas. A palavra de ordem, na esteira das doutrinas de Santo Agostinho e Santo Tomás de Aquino, era a libertas ecclesia, com o direito subordinado às concepções teológicas da Igreja ${ }^{7}$. A evolução histórica de tal relação passa, de acordo com Jónatas Machado, por três momentos: momento hierárquico (afirmação dos direitos da Igreja em relação ao Estado, marcado pela libertas ecclesia), momento regalista (afirmação dos direitos do Estado em relação à Igreja) e momento constitucional (afirmação dos direitos dos cidadãos em relação a ambos) ${ }^{8}$.

É com a Reforma Protestante que o conflito entre Igreja e Estado se decide em favor deste último, afirmando a soberania estatal como solução política para os conflitos teológicos ${ }^{9}$. A partir desse momento, há afirmação retórica e simbólica de uma liberdade religiosa, primeiramente nos EUA e a partir de então no resto do mundo ocidental até então conhecido, a reboque dos movimentos revolucionários franceses. Da libertas ecclesia, passa-se a um paradigma secular e racional ${ }^{10-11}$.

\footnotetext{
${ }^{6}$ É essa uma das principais observações feitas por Cláudio de Pereira de Souza Neto acerca da liberdade religiosa como condição para o exercício da democracia deliberativa. Sobre o ponto, cf. NETO, Cláudio Pereira de Souza. Teoria constitucional e democracia deliberativa: um estudo sobre o papel do direito na garantia das condições para a cooperação na deliberação democrática. Rio de Janeiro: Renovar, 2006, p. 162-3: "Em um contexto de pluralismo, as pessoas só se sentem partícipes da comunidade política se tal comunidade trata suas opções religiosas como dignas de igual respeito. Apenas se a autonomia privada, para que cada um realize o seu projeto particular de vida, está garantida, a política, em um contexto de pluralismo, deixa de se reduzir a uma relação amigo-inimigo. Se a comunidade política não reconhece como digna de igual respeito a opção religiosa de um cidadão, este não tem motivos para se perceber como um participante cooperativo dessa comunidade. Não garantir a liberdade religiosa corresponde a negar a própria condição de pertencimento aos crentes".

7 Para o conceito de libertas ecclesia, cf. MACHADO, Jónatas Eduardo Mendes. Liberdade religiosa numa comunidade constitucional inclusiva. Coimbra: Coimbra Editora, 1996, p. 30 e ss.

${ }^{8}$ Idem, p. 9-10.

9 WEINGARTNER NETO, Jayme. Liberdade religiosa na Constituição. Porto Alegre: Livraria do Advogado, 2007 , p. 31.

${ }_{10}$ KOENING, Mathias. Religion and public order in modern nation-states: institutional varieties and contemporary transformations. In: BRUGGER, Winfried; KARAYANNI, Michael (Eds.). Religion in the public sphere: a comparative analysis of German, Israeli, American and International Law. Heidelberg: Springer, 2007, p.6: "Esses movimentos que culminaram na Reforma Protestante foram ambos responsáveis por radicalizar a tensão entre o transcendente e a ordem mundana e tentou resolvê-lo por meio de uma reconstrução interior da sociedade. Os modos tradicionais de legitimação ruíram e o que eram até então matérias de mero protesto social - liberdade, igualdade e solidariedade - moveram-se para o centro da
} 
É neste panorama que se insere o que alguns denominaram revolução Lockeana na liberdade religiosa ${ }^{12}$, baseando-se nas ideias de John Locke sobre o tema. Cule Durham assim sintetiza os escritos do filósofo inglês acerca da liberdade religiosa: "the state can force no person to heaven"13. Conforme afirma acerca dos escritos de Locke em Carta sobre a tolerância ${ }^{14}$, o respeito à liberdade religiosa por parte de um regime político constitui mecanismo tanto de legitimação como de estabilidade deste regime ${ }^{15}$.

Desta forma, refere-se ao caráter público da religião, ultrapassando a esfera íntima da consciência de cada cidadão, ao escolher seu próprio projeto de vida de acordo com suas próprias crenças, para assumir um relevante papel no modo de expressão e exercício do poder político ${ }^{16}$. O próprio Locke reconhece, no entanto, que tal caráter da liberdade religiosa pode envolver uma série de questões tormentosas, a saber: (i) em qual extensão pode uma sociedade tolerar ou deixar de tolerar aqueles que não compartilham dos princípios de mútua tolerância e respeito? (ii) em que extensão pode uma sociedade tolerar aqueles que não mantém suas promessas e comprometimentos básicos? (iii) em que extensão pode uma sociedade tolerar aqueles que pretendem destruir a própria sociedade ${ }^{17}$ ? Tais questões deixam claro que até mesmo a liberdade religiosa está, como

sociedade. Que esse avanço para a modernidade mudou fundamentalmente a posição social da religião já é evidente no plano da semântica histórica. De fato, foi no vocabulário político pós-Reforma que o próprio conceito de 'religião' passa a ter, primeiramente, um significado genérico como um fenômeno presumivelmente distinto ('religião') em essência do récem-emergente e também essencializado domínio da ação racional interna do mundo, isto é, da economia, política, direito e ciência" (tradução livre).

${ }_{11}^{3}$ Nesse momento, de afirmação do temporal sobre o religioso, fala-se num desencantamento da religião. V. MACHADO, Jónatas Eduardo Mendes. op. Cit., p. 94: "Os autores costumam assinalar o contributo dado pelo protestantismo no sentido do desencantamento da religião. Ao negar os elementos mágicos sacramentais, quando não mesmo os próprios sacramentos, e ao desvalorizar o simbolismo dos ritos e das imagens, ele conduz a uma religiosidade racional e interior" (grifo no original).

${ }^{12}$ DURHAM JR., W. Cole. Perspectives on religious liberty: a comparative framework. In: WITTLE JR. John; VAN DER VYVAN, Johan D. (Eds.). Religious Human Rights in global perspective: legal perspectives. Cambridge: Kluwer Law International, 1996.

${ }_{13}$ DURHAM JR., W. Cole. op. Cit., p. 8.

14 LOCKE, John. Carta sobre a tolerância. São Paulo: Hedra, 2007.

15 Segundo Locke, um regime que respeite diferentes crenças irá ganhar apoio de todos aqueles que compartilham tais crenças - ou seja, tanto dos grupos dominantes como das minorias. A respeito, cf. DURHAM JR., W. Cole. op. Cit., p. 8.

${ }^{16}$ Acerca do caráter público da religião, cf. MACHADO, Jónatas Eduardo Mendes. op. Cit., p. 333-4: "Com a referência ao caráter público da religião pode querer sublinhar-se que a mesma não se contenta com uma esfera subjetivo-intelectual da crença ou adesão a uma ortodoxia, exigindo, para além disso, uma conduta ética (ortopraxis) que necessariamente transcende o âmbito restrito da devoção privada ou doméstica e se reflete nas mais diversas esferas de ação social em que os indivíduos se realizam. (...) O caráter público da religião é perfeitamente compatível com a liberdade religiosa constitucionalmente consagrada, nas suas dimensões individual e coletiva, pública e privada, e bem assim com o princípio da separação das confissões religiosas do Estado".

17 DURHAM JR., W. Cole. op. Cit., p. 12. 
qualquer direito fundamental, sujeita a limites impostos por outros direitos e interesses constitucionais e, no caso, aos postulados do livre respeito e da tolerância recíproca. A liberdade de exercício da crença religiosa, eventualmente, se chocará com outros direitos fundamentais, dentre os quais a própria liberdade de expressão de outros grupos ${ }^{18}$, o direito de privacidade e até mesmo o direito à vida, como se vê na objeção de consciência das Testemunhas de Jeová à transfusão de sangue ${ }^{19}$. Sem embargo da riqueza do tema, extrapola o espaço do presente estudo o seu maior detalhamento. De todo modo, fica o registro da complexidade da questão e de sua indissociável ligação com a abordagem aqui exposta.

É dentro desse contexto, a que já se chamou de pós-secularista ${ }^{20}$, que deve ser realizada a análise da relação Estado/religião. Com efeito, se o secularismo estatal afirmouse inicialmente com o afastamento do controle da Igreja sobre a sociedade - de forma tal que a ciência, a educação, a arte e a política quedaram livres da conformidade com o dogma teológico e com as hierarquias eclesiásticas ${ }^{21}$, não se deve ignorar que o mundo atual recebe influência direta da religião em todos os seus aspectos. Esta se destaca como um "fenômeno de massa, de notável capacidade mobilizadora e de grande força aglutinadora", que reúne mais de três quartos da população mundial e um quarto dos Estados do mundo que mantém vínculos formais com algum tipo de confissão ${ }^{22}$. Trata-se de um fenômeno mundial, ligado a aspectos da vida social que variam da política

\footnotetext{
${ }^{18}$ Podemos afirmar que a liberdade de exercício do culto religioso enquadra-se como uma das espécies do gênero liberdade de expressão, também assegurada constitucionalmente. Nessa esteira, tenha-se por base 0 paradigmático precedente do STF no caso Ellwanger, que consignou que a liberdade de expressão não engloba o direito à incitação ao racismo (STF, DJ 19.abr.2004, HC 82424/RS, Rel. Min. Moreira Alves, Rel. p/ Acórdão Min. Maurício Corrêa). Nos mesmos termos se colocarão os limites ao exercício do culto religioso, que deve manter-se respeitoso para com as demais crenças, povos, culturas e visões de mundo.

${ }^{19}$ Sobre o tema, remetemos a leitura a BARROSO, Luís Roberto. Legitimidade da recusa de transfusão de sangue por testemunhas de jeová. Dignidade humana, liberdade religiosa e escolhas existenciais. Disponível em: <http://www.luisrobertobarroso.com.br/wp-content/themes/LRB/pdf/testemunhas_de_jeova.pdf>. Acesso em: 27.ago.2010. Consoante afirma o autor, "(...) A liberdade religiosa é um direito fundamental, que integra o universo de escolhas existenciais básicas de uma pessoa, funcionando como expressão nuclear da dignidade humana. O Poder Público, como conseqüência, não pode impor uma religião nem impedir o exercício de qualquer delas, salvo para proteger valores da comunidade e os direitos fundamentais das demais pessoas. A pergunta que resta responder é a seguinte: pode o Estado proteger um indivíduo em face de si próprio, para impedir que o exercício de sua liberdade religiosa lhe cause dano irreversível ou fatal? Este é um caso-limite que contrapõe o paternalismo à autonomia individual. A indagação não comporta resposta juridicamente simples nem moralmente barata" (p. 27).

${ }^{20}$ WEINGARTNER NETO, Jayme. op. Cit., p. 41.

${ }^{21}$ MACHADO, Jónatas Eduardo Mendes. op. Cit., p. 93.

${ }^{22}$ As referências são de WEINGARTNER NETO, Jayme. op. Cit., p. 39.
} 
internacional à cultura $p o p^{23}$, culminando no que Mathias Koening chamou de post-secular society $^{24}$.

Neste prisma, far-se-á algumas considerações acerca do contexto da liberdade religiosa no direito norte-americano, por conta de seu pioneirismo e influência sobre outros sistemas. Em seguida, traremos lume ao cenário brasileiro, por meio de uma breve síntese da evolução constitucional da matéria e seu atual tratamento na Constituição Federal de 1988. Antes, porém, entendemos não ser possível tratar da liberdade religiosa - tema amplo e de riqueza inesgotável - sem adentrarmos, ainda que brevemente, nas bases teóricas e filosóficas que a sustentam. É o que se passa a fazer.

\section{DA LIBERDADE RELIGIOSA COMO DIREITO FUNDAMENTAL: BASES, DIMENSÕES E NATUREZA}

\section{II.1. Fundamentação ética}

Parte da doutrina afirma que a questão referente à fundamentação dos direitos humanos e dos direitos fundamentais não é de extrema importância, pois não garantiria por si só o reconhecimento e a realização destes direitos ${ }^{25}$. Neste sentido, Norberto Bobbio alega que "o problema fundamental em relação aos direitos do homem, hoje, não é tanto o de justificá-los, mas o de protegê-los. Trata-se de um problema não filosófico, mas

\footnotetext{
23 Jayme Weingartner Neto, com base em outros autores, fala numa religious resurgence no mundo contemporâneo. Conforme dá conta o autor, "a derrocada do comunismo teria solapado a última das metanarrativas seculares. O fundamentalismo islâmico vem nesse roldão, assim como o incremento da influência dos movimentos evangélicos (Moral Majority e Christian Coalition) - a mostrar a forte presença dos temas religiosos na esfera pública, a par do crescimento mundial dos evangélicos. O Papa João Paulo II tornou-se um fenômeno 'pop'; nas ciências naturais, surge o 'design inteligente'; mais recentemente, os ataques (religiosamente motivados) de 11 de setembro - tudo leva a religião a ser uma questão central da vida pública" (WEINGARTNER NETO, Jayme. op. Cit., p. 37).

${ }^{24}$ No entanto, como adverte o mesmo autor, mesmo no ambiente do estrito secularismo estatal a religião deixou de desempenhar protagonismo na esfera pública. A respeito, cf. KOENING, Mathias. op. Cit., p.16: "Em primeiro lugar, a religião nunca realmente desapareceu ou foi inteiramente privatizada dentro do contexto do tradicional Estado-nação. Ademais, múltiplas roupagens de diferenciação e aproximação entre política e religião se mostraram possíveis; até mesmo a esfera da política 'secular' foi ela própria investida, com o advento da modernidade, por aspectos carismáticos ou sagrados. 'Se a tese da secularização não mais carrega a convicção que um dia já teve', para citar Talal Asad, 'isso se dá porque os universos da política e da religião parecem se envolver muito mais do que pensamos, uma descoberta que tem acompanhado nossa crescente compreensão dos poderes do Estado-nação" (tradução livre).

${ }^{25}$ BOBBIO, Norberto. A era dos direitos. Rio de Janeiro: Campos, 1992, p. 42.
} 
político" $^{26}$.

Liderando essa porção doutrinária comumente chamada de negacionistas, Bobbio afirma que a pretensão de se encontrar um fundamento absoluto para os direitos fundamentais decorre do fato de que estes encerram fins socialmente desejáveis e que, por isso, merecem ser perseguidos. Todavia, nota-se três estorvos à busca de um fundamento irresistível para tais direitos: (i) a imprecisão na conceituação em traços nítidos do que vêm a ser direitos fundamentais; (ii) o fato de que esses direitos constituem uma classe variável no tempo - como observamos, por exemplo, no desenvolvimento do conceito de direito à propriedade, que até o final do século XVIII era considerado um direito absoluto, evidenciando, assim, a impossibilidade de se atribuir um fundamento absoluto a direitos historicamente relativos; e, por fim, (iii) a constatação de que estes direitos são heterogêneos, contendo, pois, pretensões diversas, não raro conflitantes, exigindo uma apropriada ponderação na sua aplicação ${ }^{27}$. Diante dessas dificuldades, os negacionistas argumentam que a busca por fundamentos absolutos é desprezível e pode servir de pretexto para impedir sua evolução ${ }^{28}$.

O problema desta concepção está na confiança depositada no legislador, visto que a ausência de fundamentação não necessariamente impõe um dever de respeito e promoção desses direitos, mormente, no que diz respeito ao Estado - um dos maiores violadores dos direitos fundamentais. Sendo assim, num Estado em que a liberdade religiosa não fosse reconhecida seria ainda mais difícil pleitear comportamentos com base neste direito.

Por outro lado, como uma das principais expressões dos direitos de liberdade, a liberdade religiosa compõe o grupo de direitos que limitam o poder do Estado e reservam um espaço de liberdade aos particulares ${ }^{29}$. Esta consideração parte de uma concepção individualista da sociedade e do princípio de que todos os homens são iguais. Nestes termos, podemos dizer que os direitos que emanam da liberdade religiosa se dirigem a um

\footnotetext{
26 Idem, p. 43. Para sustentar este posicionamento, esses teóricos invocam dois fatos históricos: a Declaração Universal dos Direitos Humanos (1948), que contou com a adesão de muitos Estados; e as barbáries da Segunda Guerra Mundial que tornaram tais direitos cada vez mais desejados na ordem internacional.

${ }^{27}$ Ibidem, p. 35-40.

28 RAMOS, André de Carvalho. Teoria geral dos direitos humanos na ordem internacional. São Paulo: Renovar, 2005, p. 37.

${ }^{29}$ BOBBIO, Norberto. op. Cit., p. 52.
} 
homem abstrato. Isto evidencia o fato de que os direitos de liberdade se desenvolvem na matriz do individualismo (metodológico, ontológico e ético) do jusnaturalismo. Assim, o direito à liberdade religiosa estaria dentre aqueles direitos anteriores e superiores ao direito posto.

A liberdade religiosa - como se verá adiante - teve seu florescimento histórico nas perseguições religiosas na Inglaterra, propiciando que muitos cristãos que não expressavam a fé anglicana fugissem à América. Esta situação e as preocupações dos colonos norte-americanos com a liberdade e a igualdade jurídica se consubstanciaram na Declaração de Independência (1776), exsurgindo, então, como direito assegurado por um documento jurídico positivado, numa manifestação do juspositivismo. Nada obstante, é sabida a insuficiência da fundamentação juspositivista dos direitos, eis que, num modelo onde as regras têm como critério de legitimidade a validade de sua produção, toda e qualquer lei poderá ser considerada válida ainda que contrária à intrínseca dignidade da pessoa humana.

Por tudo isso, passou-se a procurar um modelo que não afere sua validade por normas positivadas, senão em normas compartilhadas por toda a coletividade humana: os direitos morais $^{30}$. Neste, a superação das fundamentações jusnaturalistas e juspositivitas encontra alicerce no próprio ordenamento jurídico, especialmente na Constituição que, por ser eminentemente principiológica, possui normas de exigência de justiça, equidade ou qualquer outra dimensão da moral. Neste bojo, a liberdade religiosa, em sua fundamentação ética, está ligada ao reconhecimento de condições imprescindíveis para uma vida social digna ${ }^{31}$ - a exemplo de quando se assevera que tal reconhecimento qualifica as pessoas como partícipes da comunidade política, conforme já observamos.

\section{II.2.Dimensões subjetiva e objetiva da liberdade religiosa}

Em sua integridade, o direito à liberdade religiosa se concretiza em sua vertente

\footnotetext{
${ }^{30}$ Esta construção se deve, sobretudo, a Ronald Dworkin. Cf. DWORKIN, Ronald. Uma questão de princípio. São Paulo: Marins Fontes, 2000; e DWORKIN, Ronald. Levando os direitos a sério. São Paulo: Martins Fontes, 2002.

${ }^{31}$ RAMOS, André de Carvalho. op. Cit., p. 35-47.
} 
subjetiva, manifestada especialmente na liberdade de crença, de culto e de privacidade, bem como na vertente objetiva, atinente a uma organização político-administrativa do Estado que possibilite o pleno exercício dos direitos que decorrem da liberdade religiosa.

Na perspectiva subjetiva, a liberdade religiosa comporta os direitos subjetivos das pessoas que, nas palavras de Ingo Sarlet, "não se reduzem aos clássicos direitos de liberdade ${ }^{32}$. Nessa ótica, a liberdade religiosa atua como verdadeiro direito subjetivo, exigindo um comportamento negativo ou positivo de outra pessoa ou do próprio Estado. Este aspecto inclui também o direito de não ter uma religião, como desdobramento da liberdade de crença. Do ponto de vista objetivo, os direitos fundamentais são valores que balizam a atuação do Estado ${ }^{33}$. Por conta desta visão, podem ser encarados como um conjunto de valores básicos, com funções distintas dos subjetivos, superando o entendimento de que direitos fundamentais constituem um grupo de "garantias negativas dos interesses individuais". Como consequência desse reconhecimento objetivo, tais direitos "devem ter sua eficácia valorada" sob o ponto de vista da comunidade na sua totalidade, o que, por vezes, condiciona o exercício do direito subjetivo, que, então, deverá ser reconhecido por aquela. Também por isto, justifica-se a restrição a um direito fundamental - sem prejuízos ao seu núcleo essencial - em função da prevalência de um interesse comunitário ${ }^{34}$.

$\mathrm{Na}$ liberdade religiosa, a perspectiva objetiva se mostra clara na adoção ou não de uma religião oficial para o Estado e no aparelhamento deste para alocar e distribuir recursos, bem como conceder isenções tributárias para a otimização desse direito, dentre outras tantas questões referentes ao programa político adotado pelo constituinte originário

\footnotetext{
32 SARLET, Ingo Wolfgang. A eficácia dos direitos fundamentais. 4 ed. rev. atual. e ampl. Porto Alegre: Livraria do Advogado, 2004. p.163. Fazendo uso das lições de Robert Alexy, aquele autor afirma também que direitos fundamentais subjetivos integram: "a) direitos a qualquer coisa (que englobariam os direitos a ações negativas e positivas do Estado e/ou particulares e, portanto, os clássicos direitos de defesa e os direitos a prestações); b) liberdades (no sentido de negação de exigências e proibições) e c) os poderes (competências ou autorizações)" (p. 153).

${ }^{33}$ Consoante explica Paulo Gustavo Gonet Branco: "Os direitos fundamentais participam da essência do Estado de Direito democrático, operando como limite do poder e como diretriz para a sua ação. As constituições democráticas assumem um sistema de valores que os direitos fundamentais revelam e positivam. Esse fenômeno faz com que os direitos fundamentais influam sobre todo o ordenamento jurídico, servindo de norte para a ação de todos os poderes constituídos" (MENDES, Gilmar Ferreira. COELHO, Inocêncio Mártires. BRANCO, Paulo Gustavo Gonet. Curso de direito constitucional. São Paulo: Saraiva, 2009, p. 300).

${ }^{34}$ SARLET, Ingo Wolfgang. op. Cit., p.152-157.
} 
que procuram maximizar a liberdade religiosa na sociedade política.

Visto isto, devemos ressaltar que boa parte da doutrina prega a prevalência da perspectiva subjetiva em face da objetiva. Robert Alexy diz que, essencialmente, os direitos fundamentais se destinam à proteção dos indivíduos, e não da coletividade, e que, por seu caráter principiológico, como direitos subjetivos, se prestam muito mais ao seu mister do que na abordagem objetiva ${ }^{35}$.

\section{II.3. Natureza do direito fundamental à liberdade religiosa}

Passemos, então, a analisar o caráter da liberdade religiosa, ligado às dimensões subjetiva e objetiva deste direito fundamental, atentando para o fato de que, apesar da preponderância do viés subjetivo, o direito à liberdade religiosa também compõe o grupo de direitos que orientam a atuação do Poder Estatal. Estes, nas palavras de Ingo Sarlet, "não se limitam à função precípua de serem direitos subjetivos de defesa do indivíduo contra atos do poder público, mas que, além disso, constituem decisões valorativas de natureza jurídico-objetiva da Constituição, com eficácia em todo o ordenamento jurídico e que fornece diretrizes para os órgãos legislativos, judiciários e executivos" ${ }^{\text {36 }}$.

Jaime Weingartner Neto utiliza-se das lições de Jónatas Machado para discorrer sobre a natureza do direito fundamental à liberdade religiosa. Nesta linha, há de se falar em pelo menos sete perspectivas: (i) concepção teológica, na qual o direito à liberdade religiosa seria uma proteção da verdade religiosa, exaltando a superioridade de uma determinada doutrina; (ii) concepção sociológica, que afirma que esses direitos pretendem proteger os direitos adquiridos pela "confissão dominante ou tradicional"; (iii) concepção neo-republicana, que enfatiza a importância da religião na "coesão da comunidade política e no desenvolvimento das virtudes cívicas dos cidadãos"; (iv) concepção de superioridade moral, pela qual se diz que a "moral intrínseca das motivações religiosas" é superior às demais; (v) outra diretriz, que podemos chamar de concepção disciplinadora, afirma que o direito à tal liberdade procura disciplinar as relações

\footnotetext{
${ }^{35}$ Idem, p. 165

36 Ibidem, p. 152.
} 
religiosas, historicamente conhecidas pelo seu caráter coercitivo e discriminatório, incompatíveis com os valores do constitucionalismo moderno; (vi) concepção existencialista, que pondera que o direito à liberdade religiosa valoriza a "religião como 'expressão da consciência individual, dotada de especial densidade existencial e ótica"'; e, por fim, (vii) a concepção da identidade de grupos sociais, que prega que a liberdade religiosa procura realçar a "dimensão coletiva pelo lado positivo, sem descurar que a dignidade da pessoa humana é um atributo de uma rede de relações intersubjetivas $e$ interinstitucionais".

As concepções teológica, sociológica e a de superioridade moral não são compatíveis com os valores consagrados pelo constitucionalismo democrático, pois a alegação de prévia preponderância de uma determinada doutrina se choca frontalmente com a fundamental idéia de igual consideração da dignidade e liberdade de todos os cidadãos - expressão de um constitucionalismo democraticamente inclusivo. Restariam, então, as concepções neo-republicana, disciplinadora, existencialista e a da identidade de grupos sociais $^{37}$.

Sem prejuízo das demais, a diretriz que se mostra mais satisfatória é a concepção da identidade de grupos sociais, porque essa é a concepção que se assenta na igual consideração das pessoas e que melhor respeita os princípios da igualdade, formal e material; da liberdade, manifestado na autodeterminação; e da solidariedade, que considera as pessoas como parte do grupo social, sem que sejam marginalizados. Em última análise, estas características também se cristalizam no princípio da dignidade humana de tal modo, que podemos dizer que a liberdade religiosa tem como principal finalidade a proteção do valor da personalidade humana ${ }^{38}$.

\section{MODELOS ESTRUTURAIS DE RELAÇÃO ENTRE RELIGIÃO E ESTADO}

A despeito e sem a pretensão de exclusão dos inúmeros outros modelos

\footnotetext{
${ }^{37}$ WEINGARTNER NETO, Jayme. op. Cit., p. 63-66.

38 Para uma compreensão geral, veja-se: BODIN DE MORAES, Maria Celina. O princípio da dignidade humana. In: Maria Celina Bodin de Moraes. (Org.). Princípios do direito civil contemporâneo. Rio de Janeiro: Renovar, 2006, p. 1-61.
} 
representativos da relação Estado-religião, para o escopo do presente estudo, tomaremos por base os seis modelos descritos por Winfried Brugger ${ }^{39}$. Tenha-se em mente, no entanto, que, não obstante a classificação que vier a ser utilizada, poderemos encontrar, entre os dois casos extremos - quer seja, a hostilidade em relação à religião ou a teocracia - uma escala de outras variações que permite uma série de arranjos institucionais que não necessariamente violam a liberdade religiosa ou a democracia, sem prejuízo do fato de anunciarem uma religião estatal oficial ou prezarem por um estreito laicismo ${ }^{40}$.

O que se deseja frisar com essa afirmação é o fato de que jamais será possível determinar, a priori, se determinado modelo será democrático ou não. Nas duas configurações extremas, porém, há claras violações à liberdade de escolha religiosa de grupos majoritários ou minoritários que implicam em restrições desproporcionais ao próprio direito de participar da comunidade política como um todo. No entanto, entre essas hipóteses de evidentes implicações à liberdade religiosa, haverá uma série de outras formulações que podem mostrar-se, ou não, favoráveis à democracia. Esta, como se sabe, está longe de ser uma superfície plana onde apenas um fator será determinante à sua existência ou não. Pelo contrário, diversos outros fatores, resultantes da conjugação de outros direitos fundamentais, irão preponderar para a afirmação de uma sociedade democrática. A liberdade religiosa certamente não será o único desses fatores. Não obstante, como já se disse, poderá ser considerada como fator fundamental para o próprio exercício da deliberação democrática e ao sentimento de pertencimento a determinada comunidade política.

O primeiro dos seis modelos - e que se situa num dos extremos - é o da agressividade $^{41}$, que também pode ser denominado de secularismo absoluto ${ }^{42}$. Aqui, há

\footnotetext{
${ }^{39}$ BRUGGER, Winfried. On the relationship between structural norms and constitutional rights in Church-State relations. In: BRUGGER, Winfried; KARAYANNI, Michael (Eds.). Religion in the public sphere: a comparative analysis of German, Israeli, American and International Law. Heidelberg: Springer, 2007, p. 21-86.

${ }^{40}$ É a advertência feita por Shimon Shetreet, que apresenta uma classificação de cinco modelo que se aproxima muito do de Brugger. Segundo o autor, "os dois extremos dos modelos mencionados, o modelo teocrático e o modelo do secularismo absoluto, são não-democráticos, ao passo que os outros (três) modelos são democráticos no seu relacionamento com a religião" (SHETREET, Shimon. The model of State and Church relations and its impact on the protection of freedom of conscience and religion: a comparative analysis and a case study of Israel. In: BRUGGER, Winfried; KARAYANNI, Michael (Eds.). Religion in the public sphere: a comparative analysis of German, Israeli, American and International Law. Heidelberg: Springer, 2007, p. 88) (tradução livre).

${ }^{41}$ BRUGGER, Winfried. op. Cit., p. 31

${ }^{42}$ SHETREET, Shimon. op. Cit., p. 88.
} 
rejeição total de qualquer religião, isto é, há um ateísmo formal por parte do Estado. O Direito pró́be todo ato religioso, com eliminação absoluta de qualquer liberdade no que diz respeito ao seu exercício. Tal modelo, portanto, adota como prática ideológica, constitucional ou política, uma atitude abertamente anti-religiosa e hostil, forçando igrejas e grupos religiosos ao anonimato ou buscando o seu extermínio. Foi o que se viu nos Estados comunistas da ex-URSS ${ }^{43}$, cuja ideologia leninista-marxista via a religião como o ópio do povo, é dizer, como forma de manipulação de uma classe sobre a outra ${ }^{44}$. Da mesma maneira, pode-se citar o regime nacional-socialista alemão ${ }^{45} \mathrm{e}$, segundo Brugger, o modelo francês, embora de modo muito mais moderado que o dos regimes marxistas. Com efeito, na França, onde vige um modelo anti-clerical e de profundo laicismo, não há exatamente um hostilidade entre Igreja e Estado, mas uma idéia de perigo na religião. Os motivos para tal são, sobretudo, históricos ${ }^{46}$.

O segundo modelo é o da separação estrita na teoria e na prática ${ }^{47}$. Tal modelo se aproxima da visão jeffersoniana do muro de separação (wall-of-separation) entre Igreja

\footnotetext{
43 Brugger faz referência à Constituição da Albânia de 1976, que afirmava, em seu art. 37: "O Estado não reconhecerá religião de qualquer espécie e dará suporte e desenvolverá uma visão ateísta, de modo a incutir nas pessoas uma visão de mundo científica e materialista" (tradução livre).

${ }^{44}$ Acerca da visão marxista sobre a religião, cf. MACHADO, Jónatas Eduardo Mendes. op. Cit., p. 308: "A religião é vista como o ópio do povo, isto é, como uma superestrutura ideológica suportada pela classe burguesa com a finalidade de afastar as classes proletárias dos problemas econômicos fundamentais. Graças à religião, a burguesia vê consolidada e perpetuada a sua posição de domínio, ao passo que o proletariado é insistentemente persuadido a aceitar a ordem vigente como divinamente estabelecida e a transformar as suas aspirações em expectativas soteriológicas e escatológicas a realizar, não através da transformação revolucionária das estruturas econômicas e sociais existentes, mas apenas em 'novos céus e nova terra em que habitará a justiça'. Para o marxismo, a religião, a despeito de seu caráter pretensamente metafísico e transcendente, desempenha uma função política de mistificação, sublimação e conservação das desigualdades reais existentes na ordem imanente. Só o seu desaparecimento permitirá, em última instância, melhorar as condições econômicas e sociais".

45 Sobre a relação entre a ascensão do nazi-facismo e a religião, afirma MACHADO, Jónatas Eduardo Mendes. op. Cit., p. 309: "A teologia política adquire uma feição claramente estatizante, em que as finalidades de doutrina ideológica e de controle social assumem uma posição central. O fortalecimento do Estado só seria possível com o enfraquecimento das Igrejas".

46 Sobre o laicismo francês, cf. PÊCEGO, Daniel. Da educação religiosa em escolas públicas, 2007. Dissertação (Mestrado em Direito Público) - Universidade do Estado do Rio de Janeiro, mimeografado, p. 601: "Na França, os ideais da Revolução de 1789 estão de tal modo subjacentes, que se pode considerar esta nação como uma das em que mais fortemente se encontram atuando os elementos típicos do laicismo. Isso, como é óbvio, tem raízes históricas muito para além do simples ideário revolucionário, remontando a toda a tradição de independência da Igreja Católica francesa, com um galicanismo que por vezes beirou o cisma e pela identificação, por parte dos revolucionários, do Absolutismo com a religião estabelecida. (...) $\mathrm{Na}$ realidade, o que se nota é que o próprio laicismo passa a ser visto como uma religião, agora republicana, e o Estado ou um valor qualquer toma o lugar da divindade como objeto de veneração. A Comuna de Paris no período do Terror instituiu o culto à Razão e Robespierre fez o mesmo em relação ao 'Ser Supremo'. Não por acaso, a França é, ao lado do Brasil, o único local onde se erigiu um templo positivista, em que são veneradas as grandes personalidades da nação e se cultua a Sabedoria".

${ }^{47}$ BRUGGER, Winfried. op. Cit., p. 33-5.
} 
e Estado, que deve se dar tanto em termos organizacionais/estruturais - isto é, com a Igreja formalmente separada do Estado - como também em termos práticos, não permitindo o ingresso do poder político em nenhuma esfera relacionada ao religioso. Essa teria sido a doutrina defendida pelos votos vencidos no paradigmático precedente da Suprema Corte norte-americana, Everson v. Board of Education $(1947)^{48}$. A questão se deu em torno de uma lei de Nova Jersey, que destinava fundos para o transporte escolar de escolas públicas e privadas, incluindo escolas católicas. Os votos vencidos, no caso, entenderam que isso era um benefício para a religião católica e que, portanto, haveria uma violação à establishment clause, consagrada na $1^{a}$ Emenda à Constituição norte-americana. Nesses termos, qualquer suporte, mesmo que indireto, a um grupo religioso constituiria uma violação constitucional. Defendeu-se, portanto, uma rígida separação entre religião e poder estatal, não só formalmente como também substancialmente - o que, segundo os votos dissidentes, seria a única maneira de manter a neutralidade estatal em termos religiosos.

A visão predominante na Suprema Corte dos Estados Unidos em Everson v. Board of Education, porém, tem mais relação com o terceiro modelo de separação entre religião e Estado: o da separação estrita na teoria e acomodação na prática ${ }^{49}$. Consoante decidiu a maioria na Suprema Corte, a non-establishment clause não impede que escolas religiosas recebam suporte estatal. Esse é considerado, portanto, o modelo que vige nos Estados Unidos, sob a chancela de sua Suprema Corte.

Noutro célebre caso, Lemon v. Kurtzman ${ }^{50}$, a Corte desenvolveu o Lemon Test, que apresenta três critérios para avaliação da constitucionalidade de uma lei que preste auxílio à religião. Segundo tal three pronged test, a Corte deve analisar: (i) se o ato não tem um propósito secular (ou seja, a questão religiosa deve ser secundária e marginal); (ii) se o efeito primário não é a promoção ou inibição da religião (a promoção ou inibição deve ser secundária); (iii) se não provoca um envolvimento excessivo entre religião e os poderes públicos (a relação deve ser fraca ou marginal ${ }^{51-52}$. Se uma lei passar por esses três

\footnotetext{
48 Everson v. Board of Education, 330 U.S. 1 (1947).

${ }^{49}$ BRUGGER, Winfried. op. Cit., p. 35-7.

${ }^{50}$ Lemon v. Kurtzman, 403 U.S. 602 (1971).

51 BRUGGER, Winfried. op. Cit., p. 36.

52 MACHADO, Jónatas Eduardo Mendes. op. Cit., p. 315.
} 
critérios, ela poderá ser constitucional para tal modelo ${ }^{53}$.

Sob outra classificação, Shimon Shetreet não distingue entre esse modelo e o anterior, colocando-os na mesma categoria de separação entre Estado e religião. Trata-se de um modelo secular: o Estado não tem nenhum propósito religioso e nenhuma religião tem qualquer tipo de preferência. Para o autor, tal separação pode demonstrar-se de várias maneiras: quando o Estado declara-se como secular (essa seria, para ele, a situação da França); quando o Estado declara-se como "neutro" para questões religiosas (como Austrália e Espanha); ou quando o Estado separa-se dos assuntos religiosos (como, segundo o autor, os Estados Unidos). Nesse sentido, afirma que tal regime, de separação entre Igreja e Estado, não chega a definir como a religião será vista em relação ao Estado: isso poderá dar-se através de uma atitude positiva em relação à religião, através da necessidade de preservá-la (como o modelo norte-americano) ou através de uma atitude negativa para com esta, como forma de manter o caráter secular do Estado (como o caso da França $)^{54}$.

Temos visto, portanto, desde o primeiro modelo, uma espécie de gradação, que vai tornando o religioso cada vez mais próximo do Estado conforme os modelos são apresentados. Como quarto modelo, temos o da divisão e cooperação. Segundo Brugger, o exemplo mais eloqüente desse modelo, de cooperação entre religião e Estado, é o caso da Alemanha. Com efeito, a Lei Fundamental de Bonn estabelece que as igrejas são sujeitos de certos direitos, os quais o Estado deve respeitar. Ao mesmo tempo, porém, garante que não haverá nenhuma religião oficial ou igreja estatal ${ }^{55}$. Há claramente um caráter cooperativo entre poder público e religião, através de, a título de exemplo, contratos públicos com igrejas, termos de cooperação acerca da administração de cemitérios, apoio religioso em estabelecimentos prisionais, organização de aulas de religião em escolas

\footnotetext{
${ }^{53}$ Para mais detalhes sobre a aplicação do Lemon Test para outros casos da Suprema Corte, e uma crítica à sua utilização, cf. MACHADO, Jónatas Eduardo Mendes. op. Cit., p. 316 e ss.

54 SHETREET, Shimon. op. Cit., p. 89-90.

${ }^{55}$ A Constituição alemã consagra a liberdade religiosa e a separação da Igreja do Estado de forma genérica nos arts. 4(1) e 4(2). No seu art. 140, a Lei Fundamental de Bonn faz referência a dispositivos da Constituição de Weimar, de 1919, que tratam da relação do Estado com a religião, que continuam vigentes na atual ordem constitucional. Segundo estabelece a Constituição de 1919, as igrejas terão personalidade de acordo com a lei civil (art. 137); todos os grupos religiosos devem gozar de iguais direitos (art. 137); os domingos e dias religiosos são considerados feriados (art. 139), é permitida a assistência religiosa nas instituições públicas (art. 140), entre outras coisas.
} 
públicas, entre outros ${ }^{56}$.

Semelhante a tal modelo é o de religiões reconhecidas a que alude Shetreet, no qual o Estado não adota nenhum tipo de religião oficial, embora regule diversos aspectos da vida religiosa, prezando por uma cooperação entre religião e Estado numa série de $\operatorname{aspectos}^{57}$.

De acordo com as considerações feitas, é fácil depreender que é esse o modelo mais próximo da Constituição Federal brasileira de 1988 como da própria prática nacional. Com efeito, diversas das previsões constantes na Lei Fundamental de Bonn deram azo a normas semelhantes no texto constitucional brasileiro, como as relativas à assistência religiosa e à educação religiosa em escolas públicas. Ao tema específico da Constituição brasileira se voltará adiante.

Como penúltimo e quinto modelo, há o da unidade formal com divisão substantiva $^{58}$. Aqui, haverá o reconhecimento de uma religião oficial por parte do Estado, porém aquela se apresenta materialmente separada deste ${ }^{59}$.

Nesse sentido, tal separação substantiva manifesta-se quando (a) as duas entidades apresentam estruturas diferentes; (b) as duas entidades almejam objetivos dessemelhantes (bem comum vs. salvação); (c) as duas entidades têm um processo decisório diferente e separado; (d) a Igreja não exerce autoridade política; e (e) a liberdade religiosa dos seguidores da religião oficial e não-oficial é largamente respeitada. Seria esse, assim, o modelo de Reino Unido, Grécia e Israel ${ }^{60}$. Dessa forma, apesar de esses Estados reconhecerem religiões oficiais, ligadas até mesmo a aspectos políticos do Estado (veja-se, por exemplo, a ligação histórica da monarquia inglesa com o anglicanismo), tal reconhecimento não deverá implicar em desrespeito para com outros grupos religiosos ou pessoas não-religiosas, tampouco significará prerrogativas especiais para a religião tida como oficial.

\footnotetext{
${ }^{56}$ BRUGGER, Winfried. op. Cit., p. 38-9.

${ }^{57}$ SHETREET, Shimon. op. Cit., p. 92.

58 BRUGGER, Winfried. op. Cit., p. 42.

59 Segundo Shetreet, "a diferença entre esse modelo e o modelo da teocracia está na forma de relação perante outras religiões e pessoas não-religiosas. Enquanto o modelo teocrático não tolera outras religiões e grupos não-religiosos, o modelo das igrejas estabelecidas é democrático (pelo menos no que diz respeito à liberdade de religião)" (SHETREET, Shimon. op. Cit., p. 91) (tradução livre).

${ }^{60}$ BRUGGER, Winfried. op. Cit., p. 42.
} 
Tenha-se em mente que, ainda nesse modelo, não parece o Estado querer afirmar uma verdade absoluta acerca do religioso e impor tal verdade aos seus cidadãos. Está longe dos fins de um Estado que se queira democrático afirmar por si próprio um projeto de vida ou a veracidade de uma crença religiosa. $\mathrm{O}$ reconhecimento de uma religião em detrimento de outra tem sua origem em aspectos históricos ou sociológicos ${ }^{61}$.

Por fim, e atingindo o outro extremo de nossa gradação de relação entre religião e Estado, há o sexto e último modelo, o da unidade formal e substantiva, que nada mais é do que a famosa teocracia. Por este, há apenas uma religião oficial, proibindo-se as demais. Dessa forma, a aproximação religião-Estado é total e completa, a ponto de se confundirem: as obrigações legais são vistas como deveres religiosos e os atos ilegais são considerados pecados.

Seria esse o modelo que seguem certos países muçulmanos - dos quais os exemplos mais claros são o Afeganistão pré-intervenção militar da ONU, sob o regime do Talibã, e o Paquistão ${ }^{62}$, embora em alguns o seja de forma mais moderada. Uma teocracia mais branda seria aquela em que os líderes religiosos e políticos são pessoas distintas, - ainda assim, um grupo ainda exerce muita influência sobre o outro.

De acordo com Jónatas Machado, as conseqüências da adoção desse tipo de modelo são, dentre outras, a incitação a guerras santas, cruzadas, inquisições; discriminação no acesso a cargos públicos; utilização de fundos estatais para o financiamento da atividade religiosa; perseguição e julgamento dos "não-fiéis" (e, portanto, hereges), com a implantação da pena de morte nesses casos e quando da prática de conduta não compatíveis com os valores religiosos (como adultério e homossexualismo) ${ }^{63}$.

\section{A LIBERDADE RELIGIOSA NOS ESTADOS UNIDOS DA AMÉRICA}

\footnotetext{
${ }^{61}$ É a observação feita por PÊCEGO, Daniel. op. Cit., p. 41: "Trata-se de um reconhecimento especial que uma religião pode ter, não por um critério estrito de veracidade, uma vez que - como já afirmado - o Estado não tem competência para definir a religião verdadeira, mas sim segundo um critério sociológico, temporal, ou seja, na medida em que determinada religião constitua um elemento temporal integrador para o bem comum da nação".

${ }^{62}$ A respeito do Paquistão, Brugger faz referência a uma decisão de sua Suprema Corte que esta afirma, de forma expressa, que num país muçulmano não é necessária a proteção estatal a outras crenças religiosas. As manifestações do direito internacional, frente à questão da religião no Paquistão, seriam irrelevantes para a lei islâmica. Esta, segundo a Corte, estaria acima de todas as leis estatais, incluindo a própria Constituição (BRUGGER, Winfried. op. Cit., p. 47).

${ }^{63}$ MACHADO, Jónatas Eduardo Mendes. op. Cit., p. 305.
} 


\section{IV.1. A relação Estado-Igreja no período colonial e a Constituição de 1787}

Desde o início da história colonial norte-americana, diversos padrões de relacionamento entre o Estado e a Igreja se fizeram presentes. A primeira declaração da Virgínia (1606) já continha leis que buscavam tutelar certa uniformidade de crença e fornecer apoio financeiro à Igreja Anglicana. Outras colônias seguiram o mesmo caminho estabelecendo o Anglicanismo desde o início, ao menos nominalmente (Geórgia, Carolina do Norte, Carolina do Sul e Maryland). Delaware, Nova Jersey, Rhode Island e Pensilvânia, por sua vez, adotaram políticas religiosas amplamente liberais com o intuito de atrair colonos e desenvolvimento econômico. Massachusetts, em contrapartida, conta com um célebre histórico de perseguições, onde figuram banimentos, execuções e os decantados julgamentos das "bruxas" de Salem.

A despeito de nove das treze colônias originais haverem estabelecido alguma religião, após a Guerra Revolucionária a tônica foi o não estabelecimento, orientação sedimentada, por exemplo, na Constituição de Nova York de 1777. Neste bojo, outros estados agiram para implantar "múltiplos estabelecimentos", modelo em que o estabelecimento de uma religião não se restringia à escolha de apenas uma Igreja oficial para o Estado, mas, ao contrário, significava preferencialmente o apoio público para uma série - ou mesmo todas - as Igrejas ${ }^{64}$. No momento em que ratificaram a Bill of Rights, apenas três Estados ainda mantinham estabelecimento de alguma espécie: Massachusetts (até 1833), New Hampshire (até 1819) e Connecticut (até 1818).

O termo estabelecimento, como nota Barry Adamson, não é autoexplicativo. Todavia, considerado dentro do contexto religioso norte-americano ao longo dos anos 1600 e 1700, torna-se universalmente compreensível. Denota a existência de uma única e dominante instituição eclesiástica, que goza do status de preferida, financiada e protegida

\footnotetext{
${ }^{64}$ LEVY, Leonard Williams. The Establishment Clause: religion and the First Amendment. $2^{\mathrm{a}}$ ed. Chapel Hill: University of North Carolina Press, 1994, p. 10: "De fato, no momento da elaboração da Primeira Emenda, todos os estabelecimentos que ainda existiam na América eram gerais ou múltiplos estabelecimentos de todas as igrejas de cada Estado-membro, algo desconhecido na Europa com a qual os americanos estavam familiarizados" (tradução livre).
} 
pelo governo, consubstanciando uma união indistinguível ${ }^{65}$.

Apesar de se verificar amplo domínio anglicano no Sul ou da Igreja Congregacionalista na região da Nova Inglaterra, o fato é que todas elas estavam cercadas de minorias dissidentes (Batistas, Metodistas, Luteranos, Quakers, entre outros), que não deixaram de lutar pelo direito de praticar sua fé abertamente e sem a influência coercitiva das religiões dominantes, garantindo-se, assim, a emergência da liberdade religiosa.

Por ocasião da ratificação da Constituição norte-americana, ao menos sete Estados proibiam por lei o clero de servir em alguns - quando não todos - cargos políticos. Ademais, onze dos treze Estados impunham provas de religiosidade para acesso aos cargos públicos, exames que requeriam uma profissão de fé cristã ou uma afirmação da crença em Deus. Através do século seguinte, a imposição de tais provas restritivas sucumbiu, à exceção de Maryland e do Tenessee, onde se mantiveram restrições desta natureza, em algum grau, até a década de 1970.

Na Constituição norte-americana, originalmente, só havia uma menção à religião, em seu Art. $6^{\circ}, 3^{66}$. O que a Carta fez não foi senão abrir as portas para a candidatura de clérigos a qualquer cargo público do governo federal, ainda que ao menos sete Estados proibissem isto. Este dispositivo constitucional gerou intensos debates ao longo do processo de ratificação, tendo a opinião pública protestado contra a possibilidade de judeus e "papistas", dentre outros, serem potenciais candidatos a cargos públicos no novo governo. Mais do que isso, gerou protestos o fato de a nova Constituição ser um documento inteiramente secular, sem qualquer menção ao nome de Deus, engendrando assim uma grande campanha para frustrar sua ratificação caso não se introduzisse um expresso reconhecimento do Criador. Aqueles que lideraram esta campanha enfrentaram os defensores da redação original ao longo dos anos de 1787 e 1788, tendo vencido estes

\footnotetext{
65 ADAMSON, Barry. Freedom of religion, the First Amendment, and the Supreme Court: how the Court flunked history. Gretna: Pelican Publishing Company, 2008, p. 19-20. Nesta passagem, o autor constata que, em face da evolução do tratamento dispensado ao tema no país, chega a causar espanto uma análise retrospectiva: "Séculos depois, esquecemo-nos que, na América pré-revolucionária, Igrejas "de estabelecimento" dominavam o cenário religioso. Um estabelecimento (ou uma Igreja "estabelecida") resta há tanto removido da experiência e entendimento contemporâneos que precisamos ser lembrados do papel onipresente assumido pelos Estados e governos locais na administração dos assuntos eclesiásticos" (tradução livre).

66 "No religious test shall ever be required as a qualification to any office or public trust under the United States". Em tradução livre, "nenhuma prova religiosa poderá ser requerida como qualificação para qualquer cargo ou função pública nos Estados Unidos".
} 
últimos ${ }^{67}$.

\section{IV.2. Bill of Rights: a Primeira Emenda}

Havia outra característica na Constituição norte-americana que gerava insatisfações por parte dos mais diversos setores: ela não encerrava qualquer declaração de direitos, a despeito de alguns Estados já terem aprovado suas próprias. Também as dissidências religiosas (notadamente Batistas, Metodistas, Quakers e Deístas) difundiam o clamor por uma declaração, nas áreas onde tinham mais força, comprometidos com a idéia de liberdade religiosa.

A 25 de setembro de 1789, o Congresso norte-americano aprovou sua Bill of Rights, composta por dez Emendas Constitucionais. A redação definitiva da Primeira Emenda, no que concerne ao tema da liberdade religiosa, quedou: "Congress shall make no Law respecting an establishment of religion, or prohibiting the free exercise thereof (...)"68.

De ordinário, se extrai desse trecho da Primeira Emenda duas grandes cláusulas: $(i)$ a chamada Cláusula do Estabelecimento (que, na verdade, prevê o não estabelecimento de uma religião estatal) e (ii) a Cláusula do Livre Exercício.

Lawrence Tribe ${ }^{69}$ aduz que foram forjadas estas garantias num contexto em que as idéias de Estado e de Religião eram bem definidas e limitadas, estando o núcleo ideal da autonomia religiosa assegurado se colocados os assuntos religiosos além das competências do governo nacional. Nada obstante, a aplicação das cláusulas religiosas também aos Estados-membros (através do devido processo encerrado na Décima Quarta Emenda), a

\footnotetext{
${ }^{67}$ Mark G. Toulouse exalta a vitória do projeto secular: "A Constituição permanece intencionalmente secular, a despeito dos sérios e repetidos esforços para mudar este quadro. O povo americano, de algum modo, foi capaz de manter a percepção de que liberdade religiosa significa algo mais do que apenas a possibilidade de cristãos de várias estirpes praticarem sua fé livres da influência governamental. Esta também significava que direitos associados a todas as expressões religiosas precisam ser respeitados e tolerados se este país pretendesse seguir seus ideais. Muitos americanos, como Madison e Jefferson antes deles, há muito acreditaram que a proteção da consciência religiosa demanda uma Constituição secular. Esta não pretende garantir um espaço público secular, mas sim garantir o oposto: que a religião seja livre para falar publicamente, consoante os ditames da consciência religiosa" (TOULOUSE, Mark G. God in Public: four ways American christianity and public life relate. Louisville: Westminster John Knox Press, 2006, p. 8) (tradução livre).

68 "O Congresso não legislará no sentido de estabelecer uma religião, ou de proibir seu livre exercício (...)", em tradução livre.

69 TRIBE, Lawrence H. American Constitutional Law, $2^{\text {a }}$ ed. Mineola: The Foundation Press, 1988, p. 1154.
} 
mudança de um Estado com poderes limitados para um Estado "afirmativo" e a expansão de nossa compreensão acerca da natureza da religião mudaram este quadro, trazendo novos e diferentes significados para ambas as cláusulas, que, frequentemente, parecem conflitar. Prossegue prelecionando que a dificuldade que historicamente atormenta as Cortes quando da implementação dessas disposições tem raízes no fato de seus propósitos serem os de estabelecer um objetivo, não de escrever um estatuto.

De fato, uma das grandes dificuldades da jurisprudência constitucional norteamericana tem sido, precisamente, encontrar um meio-termo entre ambas as cláusulas religiosas, que, se expandidas a um extremo lógico, tendem a colidir ${ }^{70}$. Tanto as Cortes quanto a doutrina costumam procurar no arcabouço histórico da Primeira Emenda uma base de orientação hermenêutica. Contudo, ainda assim, surgem dificuldades, tendo em vista que os relatos históricos por vezes são vagos e muitos dos problemas que hoje se apresentam jamais foram imaginados por qualquer um dos framers $^{71}$.

Firmou-se precedente no sentido de que ações plausivelmente tidas como obrigatórias em função do livre exercício não seriam proibidas pela "establishment clause" ${ }^{, 72}$. Há, portanto, casos em que é muito difícil precisar a intersecção, visto que cada cláusula pode potencialmente orientar o intérprete a tomar decisões distintas. Deve-se, pois, e a despeito da imprecisão que persiste, buscar uma "zona de harmonia admissível" (zone of permisseble accommodation $)^{73}$, onde a cláusula do livre exercício domina a intersecção, permitindo a composição dos interesses religiosos.

\section{IV.3. A Cláusula do Estabelecimento}

Em relação ao não estabelecimento - cláusula contida no trecho "Congress shall

\footnotetext{
${ }^{70}$ TRIBE, Lawrence H. op. Cit., p. 1157.

${ }^{71}$ Para os chamados framers, ou seja, a parcela dos Fouding Fathers que participaram como delegados na Convenção Federal da Filadélfia, as cláusulas eram compatíveis, quando não complementares. Para muitos doutrinadores, trata-se simplesmente de duas faces da mesma moeda, possuindo esta um lado relativo à "separação" e outro à "liberdade" (PFEFFER, Leo. The Unity of the First Amendment Religion Clauses. In: WOOD JR., James E. (editor), The First Freedom: religion and the Bill of Rights, p. 134. apud TOULOUSE, Mark G. God in Public: Four ways American christianity and public life relate. Louisville: Westminster John Knox Press, 2006).

${ }^{72}$ Wallace v. Jaffree, 472 U.S. 38, 83 (1985)

${ }^{73}$ Quem propõe esta solução é Lawrence Tribe, reconhecendo as dificuldades inerentes ao tema. V. TRIBE, Lawrence H. op. Cit., p. 1169.
} 
make no Law respecting an establishment of religion...", entende-se que, ao proibir-se a excessiva identificação da Igreja com o Estado, está-se a assegurar que este não se intrometa demasiadamente na liberdade religiosa. Utilizada pelo Justice Hugo Black no já abordado caso Everson v. Board of Education, a metáfora jeffersoniana do muro de separação tem sido marcante na abordagem da Suprema Corte em matéria de não estabelecimento, até mesmo hodiernamente.

Enquanto a maioria da população norte-americana tinha certa homogeneidade de crenças, em face do amplo domínio do Protestantismo até a Segunda Guerra Mundial, não houve maiores dificuldades em lidar com esta questão. Entretanto, a partir da segunda metade do século XX, com a proliferação do pluralismo religioso, as dificuldades cresceram. E a cláusula se presta exatamente a isso: desativar um barril de pólvora, que não poderia ficar a mercê de uma explosiva mistura entre política e religião ${ }^{74}$.

\section{IV.4. A Cláusula do Livre Exercício}

Similarmente, ao deixar as escolhas religiosas à livre consciência dos individuais, em razão da cláusula do livre exercício, busca-se um meio de assegurar que Estado e Igreja não se unam para criar os diversos perigos e divisões inerentes a tal promiscuidade, amplamente verificados ao longo da História da Humanidade. Corresponde à segunda metade da porção da Primeira Emenda que concerne à liberdade religiosa, quer seja: “ ... or prohibiting the free exercise thereof'.

Ao passo que a outra cláusula tem cunho estrutural (diz com a relação IgrejaEstado), esta protege os direitos religiosos individuais, permitindo que os indivíduos se expressem livremente. Protege os grupos e/ou organizações religiosas somente na perspectiva dos indivíduos que possuem direitos religiosos que lhes compõem ${ }^{75}$.

O primeiro caso apreciado pela Suprema Corte, envolvendo centralmente este

\footnotetext{
74 Esta é a síntese de Levy, que discorre: "A cláusula do estabelecimento da Primeira Emenda faz mais do que sustentar a liberdade de religião, que a mesma emenda separadamente protege. Dada a extraordinária diversidade religiosa de nossa nação, a cláusula do estabelecimento serve para despolitizar a religião; ajuda, deste modo, a desativar uma situação potencialmente explosiva. A cláusula substancialmente retira assuntos religiosos das urnas eleitorais e da política" (LEVY, Leonard Williams. op. Cit., p. xiii) (tradução livre).

75 TOULOUSE, Mark. op. Cit., p. 26.
} 
dispositivo ocorreu quando mórmons desafiaram leis que proibiam múltiplos casamentos ${ }^{76}$. Sua primeira aplicação aos Estados, todavia, deu-se somente em 1940, no caso Cantwell v. Connecticut $^{77}$. A Décima Quarta Emenda à Constituição norte-americana encerra a cláusula do due process of law, prevendo sua aplicação aos Estados-membros da Federação. Aprovada em 1868, após a Guerra Civil, tal emenda visava garantir que os escravos libertos recebessem seus direitos civis integralmente. O Devido Processo, essencialmente, prevê a existência de direitos inerentes aos seres humanos que afastam a possibilidade de os Estados lhes violarem sem claras e amplamente justificáveis razões. In casu, a Suprema Corte entendeu que o livre exercício da religião estava necessariamente incluído dentre tais direitos, incorporados assim os previstos na Primeira Emenda ao rol dos protegidos pela Décima Quarta.

\section{A LIBERDADE RELIGIOSA NO DIREITO CONSTITUCIONAL BRASILEIRO}

Como se sabe, a liberdade religiosa, da mesma forma que qualquer direito fundamental, não foi um conceito fabricado a partir de um dado momento histórico, mas sim construído lentamente a partir do próprio contexto social, político e ideológico. A partir de agora, far-se-á breve estudo da evolução do seu tratamento nas Cartas Constitucionais brasileiras. Nessa esteira, ao analisá-las, imperioso será também passar

\footnotetext{
${ }^{76}$ Reynolds v. United States, 98 U.S. 145 (1879). Quando se declarou que a poligamia seria uma crença oficial da comunidade mórmom, a reação pública levou a uma resposta do Congresso, aprovando o "Morril Act" (1862), que proibia a prática em todo o território dos Estados Unidos. George Reynolds, condenado pela Corte de Utah em 1875, apelou a Suprema Corte, que afirmou que o livre exercício garante absoluta liberdade de crença, mas não de ação. A Corte aceitou as alegações de Reynolds de que se tratava de prática religiosa, mas concluiu que ela não seria admissível numa sociedade civilizada. Criou-se assim a doutrina "belief-action" que, a despeito de ter sido utilizada para decidir um segundo caso mórmom relacionado à poligamia - Davis v. Beason, 133 U.S. 333 (1890) - tem sido raramente aplicada como única justificativa dada pela Corte e é tida como bastante restritiva.

77 Cantwell v. Connecticut, 310 U.S. 296 (1940). Na década de 1940, muitos casos chegaram a Suprema Corte envolvendo religiosos Testemunhas de Jeová. Newton Cantwell e seus dois filhos foram acusados de violação legal por terem difundido idéias anti-católicas e distribuído material religioso em um bairro predominantemente católico. Em vez de lançar mão da doutrina "belief-action", a Suprema Corte examinou cuidadosamente o conflito à luz dos interesses do Estado em preservar a paz e do governo em proteger 0 livre exercício da religião. Concluiu, por unanimidade, que o caso não constituía "um claro e presente perigo a um substancial interesse do Estado". Esta doutrina do "claro e presente perigo", utilizada pela primeira vez pelo Justice Holmes em 1919, apresentava uma proteção muito mais extensa ao livre exercício. Fazendo novo uso da doutrina do "claro e presente perigo", três anos depois, a Suprema Corte alterou um entendimento anterior, declarando inconstitucional a exigência de saudação da bandeira nacional - $W$. Virginia State Bd. Of Education v. Barnette, 319 U.S. 624 (1943).
} 
pelo seu contexto histórico, para entender o que quis dizer o constituinte e qual era a realidade então vigente. Tarefa essa que não é fácil no cenário constitucional brasileiro vítima das instabilidades e paixões políticas passageiras, que por longo tempo encararam as Cartas Constitucionais como mero instrumento de legitimação de governos transitórios, ou apenas documentos formais de recomendação política ao Parlamento, todavia sem aplicabilidade e efetividade $\operatorname{concretas}^{78}$. O resultado foi um grande número de Constituições que pouco lograram aplicação prática, engendrando a crônica e gigantesca distância entre a promessa e a realidade tão típica de nossa República.

De fato, desde os primórdios da colonização portuguesa, o fenômeno religioso, representado pelo poderio da Igreja, interferiu de forma preponderante na construção de nosso país, participando em áreas que vão desde a educação e o comércio até a política. Mesmo após a declaração da Independência em relação a Portugal, a 7 de setembro de 1822, havia uma ligação ainda muito estreita com o Estado português, inclusive com a manutenção das relações entre Estado e Igreja ${ }^{79}$.

A Constituição Imperial, outorgada em 25 de março de 1824, encerrava em seu Preâmbulo: "DOM PEDRO PRIMEIRO, POR GRAÇA DE DEOS, e Unanime Acclamação dos Povos, Imperador Constitucional, e Defensor Perpetuo do Brazil (...)”, já deixando claro o culto religioso pelo qual haveria de se filiar. $\mathrm{O}$ art. $5^{\circ}$ desta mesma Constituição ratificava a opção do Império, proclamando a religião católica como oficial, positivando, apenas, uma questão de fato ${ }^{80}$. 78 Dentro da célebre classificação de Karl Loewenstein entre Constituição nominal, semântica e normativa, as
Constituições brasileiras, sobretudo a de 1937 e $1967 / 69$, podem ser encaixadas no conceito de Constituição
semântica: "subalterna formalização do poder político existente, para o exclusivo benefício dos detentores do
poder de fato, que dispõe do aparato coativo do Estado. Se não houvesse nenhuma Constituição formal ou
escrita, a vida institucional não seria perceptivelmente diferente" (BARROSO, Luís Roberto. O direito
constitucional e a efetividade de suas normas. Rio de Janeiro: Renovar, 2006, p. 64).
79 Não obstante a diferença entre o processo de Independência do Brasil com a dos outros países latino-
americanos, cabe lembrar que "imediatamente após a independência, na maioria dos países latinos-
americanos a religião católica permaneceu como religião de Estado. Até os chamados governos liberais - de
cunho fortemente anticlerical - mantiveram essa característica, porque Ihes permitia reivindicar, perante o
Vaticano, a continuidade do regime do Padroado (...)" (HORTAL, Pe. Jesus. O princípio da liberdade religiosa
e o ordenamento jurídico. In: PEIXINHO, Manoel Messias; GUERRA, Isabela Franco, NASCIMENTO FILHO,
Firly (Orgs.). Os princípios da Constituição de 1988: Rio de Janeiro: Lúmen Juris, 2006, p. 310).
80 Em coerência com as observações já feitas acerca da declaração de uma religiosa oficial por parte do
Estado, afirma SCAMPINI, José. A liberdade religiosa nas Constituições brasileiras. Primeira Parte. Revista
de Informação Legislativa. Brasília, n. 41, p.110, 1974: "Não foi a Constituição que fez da Religião Católica a
religião do Brasil. Não foi um código político que fez do catolicismo a religião nacional. O catolicismo foi
reconhecido pelo legislador como um fato anterior; a religião católica foi aceita por ele como um direito
adquirido da Nação brasileira. (...) Nesse sentido deve-se interpretar o art. 5o da Constituição: um 
Como reflexo desta opção, a Constituição mandava, por exemplo, que o Imperador jurasse manter a religião católica como a oficial (art. 103) e estabelecia que um dos requisitos para alguém ser eleito deputado era a profissão da fé católica (art.95) ${ }^{81}$. Por outro lado, o seu art. $5^{\circ}$, ao mesmo tempo em que consagrava a religião católica como oficial do Estado, aludia à tolerância de outros cultos. Da mesma forma, dizia o art. 129, V: "Ninguem póde ser perseguido por motivo de Religião, uma vez que respeite a do Estado, e não offenda a Moral Publica" ${ }^{\$ 2}$. Todavia, ao contrário do que num primeiro momento se pode supor, ser a religião oficial do Império não significava liberdade total à Igreja - na verdade, esta estava sujeita ao poder da Coroa ${ }^{83}$.

Em 24 de fevereiro de 1891, a Assembléia Constituinte convocada pelo Governo Provisório promulgou a primeira Constituição republicana brasileira, inspirada, sobretudo, na Constituição norte-americana de 1787.Esta engendrou uma radical alteração na estrutura relacional entre Estado e Igreja: a completa cisão entre ambos. Consolidou, assim, uma situação que já se verificara por ocasião do advento do Decreto 119-A, de 7 de janeiro de 1890.

Nos últimos anos do Império, a relação entre o clero e o Estado se tornava cada vez mais delicada. Importante indício do estremecimento das relações entre as instituições foi a denominada questão religiosa. Após a proclamação da República, a 15 de novembro de 1889, coube a Rui Barbosa conciliar as relações entre o novo governo e a Igreja Católica. Foi ele quem produziu o Decreto $\mathrm{n}^{\circ} 119$-A, de 7 de janeiro de 1890, cumprindo com a objetivada cisão sem demonstrar a intenção de retaliar a Igreja.

Sem prejuízo dos elogios à independência conquistada, o Episcopado insurgiu-se

reconhecimento de que a maioria dos cidadãos brasileiros é católica; um reconhecimento oficial meramente externo e nada mais".

81 Discorrendo sobre este ponto, José Scampini relata que "essa exigência, segundo alguns autores, é compreensível pela razão política de que, se um dia houvesse na Câmara dos Deputados uma maioria nãocatólica, poderia haver a tentativa de eliminar da Constituição o art. $5^{\circ}$ " (SCAMPINI, José. op. Cit., p.112).

${ }^{82}$ Deve-se observar, entretanto, que falar numa liberdade religiosa absoluta no período do Império é algo que deve ser visto cum granus salis, pois o próprio ordenamento jurídico impunha limitações ao exercício de determinadas crenças. O culto não-católico, por exemplo, deveria se limitar ao âmbito doméstico e não ofender a moral pública. De igual sorte, o Código Criminal do Império, de 1830, tipificava como crimes a propagação de cultos ou atos atentatórios à existência de Deus, à imortalidade da alma e à moral.

SILVA, José Afonso da. Comentário contextual à Constituição. São Paulo: Malheiros, 2005, p. 251: "Em verdade, não houve no Império liberdade religiosa, pois, se o culto católico gozava de certo privilégio e podia realizar-se livremente, muitas restrições existiam quanto à organização e funcionamento da religião oficial, a ponto de se reconhecer, hoje, que ela era uma religião manietada e escravizada pelo Estado, através da sua intervenção abusiva na esfera da Igreja". 
contra o novo regime estabelecido com o decreto, criticando sua separação do Estado e temendo ter para si o mesmo tratamento dispensado àquelas que chamava de $\operatorname{seitas}^{84}$. A importância do decreto em exame consiste no seu papel de vanguarda, tendo antecipado a essência das profundas mudanças no regime que disciplinava a relação do Estado brasileiro com a Igreja Católica.

José Scampini salienta que esta Constituição não fez distinção e não falou das liberdades de consciência nem de crença, somente referiu-se à liberdade de culto, que, ao seu ver, compreende a de orar e a de praticar os atos próprios das manifestações exteriores em casa ou em público, bem como a de recebimento de contribuições para tal.

A chamada escusa de consciência aparece na Carta Republicana (art. 72, § 28) ainda em estado embrionário. Nos arts. $72, \S 7^{\circ}$ e 11 encerrava-se o núcleo da separação entre o Estado e a Igreja, consolidando o que dispusera o Decreto 119-A e configurando a neutralidade do Estado leigo perante as religiões estabelecidas no país. Também neste sentido, o art. 72 consignava a laicidade do ensino e a secularização dos cemitérios.

Com a Revolução Constitucionalista ${ }^{85}$, no final do ano de 1932 e começo de 1933, a campanha eleitoral para a Assembléia Nacional Constituinte tomou conta do país. As forças políticas se reorganizaram para aquela que seria a primeira eleição desde a vitória da Revolução de 1930. A Igreja Católica buscava sua afirmação e o aumento de sua influência na vida política do Brasil $^{86}$.

\footnotetext{
${ }^{84}$ Nesse sentido, SCAMPINI, José. A liberdade religiosa nas Constituições brasileiras. Segunda Parte. Revista de Informação Legislativa. Brasília, n. 42 p. 386-7, 1974.

${ }_{85}$ Como se sabe, a Revolução Constitucionalista representou uma reação de diversos setores políticos paulistas contra o novo rumo tomado pelo país sob a direção de Vargas. Dentre as reivindicações, exigia-se do governo a criação de uma Carta Magna que regesse a legislação do país - algo que Vargas vinha adiando - bem como eleições gerais para Presidente da República. Apesar de derrotado militarmente, o movimento logrou forçar Getúlio a convocar uma Assembléia Constituinte.

${ }^{86}$ Destacam-se, para os interesses do presente trabalho, as chamadas Emendas Religiosas. "Nunca, na vida republicana brasileira, a Igreja Católica teve presença política tão importante quanto nos anos 30 . Estes eram, no entanto, os anos de Getúlio Vargas, gaúcho criado na tradição castilhista, positivista e anti-clerical de seu estado. O pacto selado naqueles anos entre a Igreja e o regime getulista é um episódio ainda pouco estudado e compreendido. (...) A Igreja buscava, neste momento, restabelecer sua posição e direitos que havia perdido quando da implantação da República. O ensino religioso nas escolas públicas era talvez o mais importante; além disto, o reconhecimento de efeitos civis para os casamentos religiosos, e o direito de os sacerdotes servirem o Exército não como soldados, mas como capelães. Eram estas as "emendas religiosas" que terminaram, finalmente, incorporadas à Constituição de 1934. Nesta época, a desconfiança entre a Igreja e o Estado já se havia transformado em um pacto de colaboração, que ganharia mais tarde sua dinâmica própria" (SCHWARTZMAN, Simon. A política da Igreja e a educação: o sentido de um pacto. Religião e Sociedade, n. 13, p. 108-27, 1986. Disponível em: <http://www.schwartzman.org.br/simon/alceu.htm>. Acesso em: 16.out.2009).
} 
Analisando os dispositivos da Carta de 1934, percebe-se, nos incisos II e III do art. 17, a proibição de subvenções oficiais ou de relações de dependência entre Estado e Igreja. Apesar disso, as liberdades de consciência e de crença foram tornadas explícitas no art. 113, ao lado do já consagrado livre exercício do culto.

Os ministros religiosos que, pela interpretação da Lei Maior de 1891, perderiam seus direitos políticos caso se eximissem do serviço militar qualquer que fosse este, tiveram, na Constituição de 1934, seu regime abrandado, em face do novo art. $163, \S 3^{\circ 87}$, que discriminou quais seriam os serviços prestados, mais compatíveis com a orientação religiosa.

O ensino religioso, que antes era proibido nas escolas públicas, com a Constituição de 1934 tornou-se facultativo, conforme a confissão religiosa do aluno, manifestada por seus pais (art. 153). Opositores propuseram emendas pelas quais o ensino religioso seria ministrado pelas comunidades religiosas interessadas ou para que a disciplina fosse substituída por outra (educação moral e cívica), mas os constituintes católicos adeptos das emendas religiosas lograram sucesso.

Em 10 de novembro de 1937, Getúlio Vargas outorgava uma nova Constituição da República. No que concerne às liberdades religiosas, a Carta de 1937 basicamente remontou ao conteúdo daquela que fora promulgada em 1891. Estas foram as duas únicas Constituições brasileiras que não se referiram ao nome de Deus. O diploma, que inaugurou o Estado Novo, em certos pontos, foi ainda mais restritivo, dando a parcelas da doutrina o entendimento de que era forte seu espírito laicista ${ }^{88}$.

No entendimento de Pontes de Miranda, a Constituição de 1937 saltou 1934 e volveu a 1891 no que tange à laicidade de Estado. O dispositivo de separação da Igreja em relação ao Estado introduzido três anos antes foi repetido, contudo com a supressão da parte que pregava a colaboração recíproca (art. 32). Tal como na Primeira República,

\footnotetext{
87 Art. $163, \S 3^{\circ}$. "O serviço militar dos eclesiásticos será prestado sob a forma de assistência espiritual e hospitalar às forças armadas".

${ }^{88}$ SCAMPINI, José. A liberdade religiosa nas Constituições brasileiras. Terceira Parte. Revista de Informação Legislativa. Brasília, n. 43,p.199, 1974: "Conhecida vulgarmente durante muito tempo como 'a polaca', por ter buscado a inspiração na Constituição da Polônia, a Carta de 1937 somente chegou a ser executada naquelas partes em que conduzia ao paroxismo o poder presidencial (...). É sintomático que a Constituição de 37 tenha desprezado ou pelo menos não tenha incluído entre os direitos e garantias individuais a liberdade de consciência que é o fundamento da liberdade de culto. Talvez a explicação desse fato resida na natureza (...) que difere de todas as outras pelo seu caráter artificial, inatural, arbitrário e ditatorial".
} 
somente a liberdade de culto foi expressamente resguardada, sem menções à inviolabilidade das liberdades de crença e de consciência (art. 122), fato temperado mediante a ressalva de seu art. 123. A Carta de 1934, entretanto, foi substancialmente conservada no tocante ao ensino religioso, facultativo na freqüência e relativo à crença do aluno, conforme os termos do art. 133.

A Constituição de 1946, que se reaproximou dos princípios democráticos e do constitucionalismo liberal, apontava num sentido de fortalecimento do princípio federativo, de uma separação de poderes mais equilibrada e do aprimoramento dos direitos e garantias individuais ${ }^{89}$.

A exemplo da Constituição de 1934, o preâmbulo da Constituição de 1946 invocava a figura de Deus. Apesar disso, em suas Disposições Preliminares, a Constituição consagrava a independência do Estado em relação à religião, prevendo a possibilidade de colaboração entre a Igreja e o Estado (art. 31, II e II). A idéia era a de cooperação em prol do interesse público.

No Capítulo II, referente aos direitos e garantias individuais, a Constituição de 1946 previa o direito à liberdade religiosa (art. 141, § $7^{\circ}$ ). Esta alusão a tal liberdade manifestase na divisão deste direito em liberdade de consciência, liberdade de crença e liberdade de culto, tendo a ordem pública e os bons costumes como seus elementos condicionantes. Contudo, vale ressaltar que o dispositivo em análise faz uma diferenciação ao qualificar a liberdade de consciência e a liberdade de crença como invioláveis e a liberdade de culto como livre ${ }^{90}$.

O direito à chamada escusa de consciência encontrava previsão legal no art. 141, § $8^{\circ}$. Já o direito de assistência religiosa era previsto no art. $141, \S 9^{\circ}$. Este já encontrava previsão na Constituição de 1934, na qual, segundo José Scampini, “o Estado era apenas

\footnotetext{
${ }^{89}$ O Brasil, que durante a Segunda Guerra Mundial apoiara os Aliados, via-se numa situação complicada: com a derrota do nazismo e do fascismo, a ordem internacional passou a se organizar em um modelo de cooperação, com forte clamor aos ideais democráticos e, sobretudo, respeitos aos direitos e garantias individuais, e, apesar disso, a Constituição de 1937 caracterizava-se pela centralização do poder político nas mãos do Poder Executivo. Assim, pode-se dizer que a redemocratização do Brasil no período de 1944-1946 foi quase uma imposição do contexto histórico. Uma importante medida foi a expedição da Lei Constitucional $n^{\circ}$ 9, de 28 de fevereiro de 1945, convocando eleições gerais.

90 Esta diferenciação nos leva a crer que a liberdade de consciência e a liberdade de crença eram consideradas absolutas, abrangendo outros direitos necessários para o seu exercício e afastando restrições; e, por outro lado, a liberdade de culto era relativa, podendo ser questionada quando contrariassem a ordem pública e os bons costumes.
} 
obrigado a permitir a assistência solicitada, presumivelmente pelos favorecidos, ao passo que segundo a de 1946, o Estado tem obrigação de promover a assistência"91. Os atuais contornos da assistência religiosa serão vistos adiante.

Após o Golpe Militar de 1964 e os sucessivos Atos Institucionais que deformaram a Constituição de 1946, o Presidente da República Castelo Branco enviou ao Congresso Nacional, em dezembro de 1966, o projeto daquela que seria a Constituição de 1967. No que diz respeito aos direitos e garantias individuais, a Carta de 1967, de maneira geral, manteve a linha da Constituição de 1946, mas teve como principal característica o fortalecimento do Poder Executivo, em detrimento do Poder Legislativo, como no caso da instituição do decreto-lei.

Sendo assim, poucas foram as modificações atinentes à liberdade religiosa ${ }^{92}$. Seu preâmbulo também invocava a Deus, porém mantinha-se a separação entre a religião e o Estado, ainda que com maiores restrições à colaboração entre o Estado e as entidades religiosas (art. $9^{\circ}$ ). A liberdade de consciência, que na Constituição de 1946 era inviolável, em sua sucessora era, tal como a liberdade de culto, considerada livre quando não contrariasse a ordem pública e os bons costumes (art. 150).

$\mathrm{O}$ art. 150 estabelecia diversas normas sobre a liberdade religiosa: a escusa de consciência ganhou uma cláusula que possibilitava a determinação, por meio de lei, dos casos em que haveria "perda dos direitos incompatíveis com a escusa de consciência"; a assistência religiosa se manteve, na ocasião, sem caráter obrigatório e nos termos da lei; e, como grande novidade da Constituição de 1967, firmou-se a igualdade sem distinção de credo religioso.

Cada dia mais o Poder Executivo se agigantava, especialmente após a edição, em dezembro de 1968, do Ato Institucional n 05, que dava ao Presidente da República amplos poderes para, por exemplo, decretar o recesso do Congresso Nacional e suspender direitos políticos de qualquer cidadão. Diante dessas mudanças, a ordem constitucional de 1969 se formalizou por meio da $\mathrm{EC} \mathrm{n}^{\circ} 01$ de 1969. Como já se observava na sua antecessora, a

\footnotetext{
91 SCAMPINI, José. A liberdade religiosa nas Constituições brasileiras. Quarta Parte. Revista de Informação Legislativa. Brasília, n. 44,p. 180, 1974.

92 Nesse sentido, GODOY, Arnaldo Moraes. A liberdade religiosa nas constituições do Brasil. Revista de Direito Constitucional e Internacional. São Paulo, n. 34, p. 164, 2001.
} 
Constituição de 1969 trazia um elenco de garantias e direitos fundamentais que na prática pouco era observado.

No que diz respeito ao direito à liberdade religiosa, as modificações foram pequenas. Sustentou-se a proteção de Deus no Preâmbulo; o art. $9^{\circ}$, II, preservou a independência do Estado frente à religião, sem prejuízo de cooperação a favor do interesse público, e acrescentou-se que tal colaboração se daria "na forma e nos limites da lei federal".

$\mathrm{O}$ art. 153 manteve as previsões referentes aos direitos à liberdade de consciência e à liberdade de culto, à escusa de consciência e à assistência religiosa. Também se conservou, entre os direitos e garantias individuais, a igualdade perante a lei, sem distinção de sexo, raça, trabalho, credo religioso e convicções políticas. Além disso, a Constituição de 1969 estipulava que o Presidente da República poderia declarar a perda de direitos políticos conflitantes com a recusa baseada na convicção religiosa (art. 149, $\S 1^{\circ}, b$ ).

Finalmente, cabe fazer uma análise mais atenta à Constituição de 1988, que surgiu no ápice de um movimento de retorno ao Estado democrático que sacudiu a sociedade brasileira na década de 80 do século passado. De um lado, a necessidade de institucionalizar uma ordem política recém implantada (ou recém reconquistada) e ainda sujeita a diversas instabilidades. De outro, a homérica missão de garantir direitos e deveres a uma sociedade ainda fragilizada e estabelecer consensos mínimos para um povo marcado notadamente pela diversidade cultural e religiosa, além de espalhado num território de dimensões continentais. Foge aos objetivos do presente estudo expor todas as vicissitudes e influências que marcaram a Assembléia Constituinte, que acabou por culminar num texto constitucional analítico e pródigo em direitos. O que devemos indagar é: que espaço o constituinte reservou para a religião e de que maneira esta foi tratada?

Basta uma leitura rápida no texto da Constituição de 1988 para se notar que a religião, de longe, não deixou de ser um assunto de relevância para o legislador constituinte. Pelo contrário, em diversos pontos do texto constitucional são feitas referências ao fenômeno religioso ${ }^{93}$.

\footnotetext{
93 Isto se denota já a partir do Preâmbulo da Constituição que, seguindo o que fizeram todos os textos constitucionais anteriores, com exceção dos de 1891 e 1937, invoca a "proteção de Deus". Não há que se tirar, porém, qualquer conteúdo jurídico de tal invocação. Nesse sentido, e na esteira da posição doutrinária
} 
Em primeiro lugar, e na esteira do que já fazia na maior parte dos textos constitucionais anteriores, foi preocupação do constituinte assegurar a liberdade religiosa como direito fundamental, garantindo "a liberdade de consciência e de crença, sendo assegurado o livre exercício dos cultos religiosos e garantida, na forma da lei, a proteção aos locais de culto e a suas liturgias" (art. 5, VI, CF/88). Nesse sentido, a Constituição pretende não impor nenhum regime especial a qualquer tipo de religião e assegura a liberdade tanto de escolher e expressar uma religião como de não aderir a nenhuma, respeitados sempre os limites a que estão sujeitos todos os direitos fundamentais ${ }^{94}$.

A Carta de 1988 ainda previu, no art. 5, VII, "a prestação de assistência religiosa nas entidades civis e militares de internação coletiva". Trata-se de disposição que deita raízes no já referido art. 141 da Constituição de Weimar, que estabelecia a assistência em instituições públicas por parte de entidades religiosas, embora tanto o dispositivo germânico quanto o nosso indiquem que apenas se deve permitir a assistência, não sendo esta obrigatória ${ }^{95}$. Vê-se que a Constituição, aqui, vai além da obrigação negativa de vedação ao Estado de impor restrições ao exercício das diversas religiões: assegura a prestação da assistência religiosa aos internos de estabelecimentos coletivos civis e militares - vale dizer, aos presos, aos militares e aos hospitalizados. Todavia, o dever do Estado exaure-se com a criação de facilidades e condições, não podendo, em razão de seu caráter laico, subvencionar ou empregar membros de uma seita ou religião para que prestem a assistência. A prestação de caráter privado, por sua vez, deve ficar a cargo dos representantes de cada religião ${ }^{96}$.

dominante, já afirmou o STF que o preâmbulo da Constituição "não se situa no âmbito do Direito, mas no domínio da política, refletindo posição ideológica do constituinte" (STF, DJ 08.ago.2003, ADI 2076/AC, Rel. Min. Carlos Velloso). No caso, o STF entendeu que o preâmbulo da Constituição Federal de 1988 não é norma de reprodução obrigatória nas Constituições estaduais.

${ }^{94}$ É a observação feita por SILVA, José Afonso da. op. Cit., p. 83: "Faz bem o constituinte em destacar a liberdade de crença da de consciência. Ambas são inconfundíveis, pois o 'descrente [di-lo Pontes de Miranda] também tem liberdade de consciência e pode pedir que se tutele juridicamente tal direito', assim como 'a liberdade de crença compreende a liberdade de ter uma crença e a de não ter crença'. Na liberdade de crença entra a liberdade de escolha da religião, a liberdade de aderir a qualquer seita religiosa, a liberdade (ou o direito) de mudar de religião, mas também compreende a liberdade de não aderir a religião alguma, assim como a liberdade de descrença, a liberdade de ser ateu e de exprimir o agnotismo. Mas não compreende a liberdade de embaraçar o livre exercício de qualquer religião, de qualquer crença, pois aqui também a liberdade de alguém vai até onde não prejudique a liberdade dos outros" (grifos no original).

95 PONTES DE MIRANDA, Francisco C. Comentários à Constituição de 1967. Tomo V. São Paulo: Revista dos Tribunais, 1974, p. 145.

${ }^{96}$ Cabe referir que o dispositivo constitucional em questão foi regulado pela Lei no 9.982/2000, que dispõe, 
Ainda no art. $5^{\circ}$, a Constituição prevê, no inciso VIII, a objeção de consciência por motivos religiosos, ao assegurar que "ninguém será privado de direitos por motivo de crença religiosa ou de convicção filosófica ou política". A objeção de consciência é uma espécie de direito de resistência que "significa a soma de motivos usados por alguém, numa pretensão de direito individual em dispensar-se de obrigação jurídica imposta pelo Estado a todos, indistintamente" ${ }^{97}$. Trata-se, portanto, de um direito do objetor, calcado na liberdade de consciência ou de crença, de desatender ao determinado em lei ${ }^{98}$.

No contexto jurídico brasileiro, a objeção de consciência encontra-se intimamente relacionada com a prestação de serviço militar alternativo, previsto em sede constitucional pelo art. 141, $\S 1^{\circ}$ da Constituição Federal ${ }^{99}$. Deve-se ter em mente, no entanto, que não se esgota nessa possibilidade - pelo contrário, pode encontrar reflexo em todos os aspectos da vida jurídica em que houver uma imposição estatal. Também não se limita a objeção de consciência à opção religiosa, podendo ser invocada, em geral, em virtude de questões morais, políticas ou ideológicas. Não se pode olvidar, porém, que o seu reconhecimento, em última hipótese, depende também da vontade estatal ${ }^{100}$.

É de muita relevância prática, ainda, a objeção de consciência contra trabalhos ou realização de concursos aos sábados ou em outros dias considerados sagrados por cultos religiosos. Nesse sentido, defendem alguns que o trabalhador deve informar previamente ao empregador sobre sua situação de impossibilidade de trabalho nestes dias - realizando a compensação em outro -, como também se recomenda que as escolas evitem marcar aulas e exames nestas datas ${ }^{101}$.

em seu art. 10: "Aos religiosos de todas as confissões assegura-se o acesso aos hospitais da rede pública ou privada, bem como aos estabelecimentos prisionais civis ou militares, para dar atendimento religioso aos internados, desde que em comum acordo com estes, ou com seus familiares no caso de doentes que já não mais estejam no gozo de suas faculdades mentais".

${ }^{97}$ BUZANELLO, José Carlos. Direito de resistência constitucional. 2ª ed. Rio de Janeiro: Lúmen Júris, 2006, p. 150.

98 GASPARINI, Diógenes. Objeção de consciência e serviço policial militar. Revista Trimestral de Direito Público. São Paulo, n. 10, p. 158, 1995.

99 A objeção de consciência em matéria de serviço militar obrigatório foi regulada pelo legislador infraconstitucional na Lei no 8.239/1991. Tal lei encontra-se regulamentada pela Portaria no 2.681 da EMFA, de 28 de julho de 1992, que estabelece em detalhes os procedimentos a serem observados no Serviço Militar Alternativo.

${ }^{100}$ BUZANELLO, José Carlos. op. Cit., p. 154.

101 WEINGARTNER NETO, Jayme. op. Cit., p. 237: "O direito individual de comemoração pública das festividades religiosas e o direito das igrejas de livre exercício das funções religiosas e de culto confluem para reforçar o direito fundamental prima facie à dispensa do trabalho e de aulas/provas por motivo religioso, a 
Ainda neste tema, há intensa discussão jurisprudencial acerca da possibilidade de dispensa ou remarcação de provas de concursos ou vestibulares que são marcadas no sábado. Tendo como base as decisões mais recentes na matéria, podem ser vislumbrados dois distintos posicionamentos sobre a questão: (i) do primado do que está definido no edital do concurso, com a obrigação de todos realizarem a prova no mesmo dia, por força do princípio da igualdade ${ }^{102}$; (ii) de consideração da liberdade de crença religiosa, como escusa justificável para que se realize a prova em outro dia ${ }^{103}$. O STF, até há pouco, não havia chegado a enfrentar a questão de modo direito. Não obstante, em dezembro de 2009, negou que alunos judeus realizassem a prova do Exame Nacional do Ensino Médio (ENEM) em outro dia que não o sábado, sintonizando-se que as primeiras das tendências apontadas $^{104}$.

Além dessas previsões, dispostas no capítulo destinado aos direitos fundamentais, a Constituição de 1988 volta a referir-se à religião em diversos outros momentos, como o estabelecimento de proibição de instituir impostos sobre templos de qualquer culto (art. 150, VI, b); de atribuição de efeitos civis ao casamento religioso (art. 226, § $2^{\circ}$ ); a proibição dos entes federativos estabelecerem “cultos religiosos ou igrejas, subvencionálos, embaraçar-lhes o funcionamento ou manter com eles ou seus representantes relações de dependência ou aliança”, ressalvando o interesse público (art. 19, I); e a possibilidade

substanciar o princípio da cooperação, devendo o Estado criar condições organizacionais e procedimentais, no âmbito laboral e educacional, para o mais amplo exercício do direito de dispensa ao trabalho e de aulas/provas por motivo religioso".

${ }_{102}$ Nesse sentido, veja-se, por exemplo, STJ, DJ 1ํ. ago.2005, AMS 161907/PA, Rel. Min. Paulo Medina: "Pelo chamado princípio da vinculação ao instrumento convocatório, impende ressaltar que a Administração Pública fica, estritamente, vinculada às normas e condições previamente definidas no edital, não podendo, no curso do procedimento licitatório, criar novas regras ou das que antecipadamente previu se afastar. (...) Se é a lei quem iguala os indivíduos, somente ela é capaz de diferenciá-los, segundo os objetivos que persegue”.

${ }^{103}$ Dentre outros, v. TRF4, DJ 08.nov.2007, AMS 200370000177031, Rel $^{\mathrm{a}}$. Des ${ }^{\mathrm{a}}$. Maria Lúcia Luz Vieira: "(...) 4. Não há como entender-se a prevalência dos princípios da legalidade e da igualdade com o sacrifício, no caso concreto, do direito à educação de aluno adepto de credo minoritário. Necessidade de respeito ao 'núcleo essencial' da liberdade de crença: liberdade de ter, não ter e deixar de ter religião e a liberdade de livre escolha da crença, de mudar e de abandonar a própria crença religiosa. Moderna doutrina de 'liberdade religiosa', compatível com o pluralismo de idéias, o princípio da não-confessionalidade, a tolerância e a diversidade de culturas, crenças e idéias. Reconhecimento, como âmbito de proteção do direito, a 'união indissociável entre crença e conduta'”.

${ }^{104}$ STF, DJ 14.mai.2010, STA-AgR 389, Rel. Min. Gilmar Mendes: “(...) Em mero juízo de delibação, pode-se afirmar que a designação de data alternativa para a realização dos exames não se revela em sintonia com o princípio da isonomia, convolando-se em privilégio para um determinado grupo religioso. Decisão da Presidência, proferida em sede de contracautela, sob a ótica dos riscos que a tutela antecipada é capaz de acarretar à ordem pública. Pendência de julgamento da ADI 391 e da ADI 3.714, nas quais esta Corte poderá analisar o tema com maior profundidade". 
de se ministrar de aulas de ensino religioso nas escolas públicas (art. $210, \S 1^{\circ}$ ).

Acerca desta última, é tema que tem gerado crescente polêmica. $\mathrm{O}$ ensino religioso nas escolas públicas é previsto também, em sede infraconstitucional, no art. 33 da Lei $\mathrm{n}^{\circ}$ 9.394/96 (Lei de Diretrizes e Bases da Educação Nacional). O texto de tal dispositivo, em sua redação inicial, dizia que o ensino religioso seria oferecido sem ônus para os cofres públicos e de acordo com as preferências manifestas pelos alunos ou por seus responsáveis. Argumentava-se na época que a previsão de não onerosidade para os cofres públicos procurava atender as disposições do art. $19, \mathrm{I}_{\mathrm{C}} \mathrm{CF}^{105}$. Previa ainda que o ensino poderia ser confessional (inciso I) ou inconfessional (inciso II).

No entanto, o art. 33 da LDB foi modificado em 1997 pela Lei ${ }^{\circ}$ 9.475, passando a prever o ensino religioso ministrado pelo Estado com a atuação dos sistemas de ensino na regulamentação dos "procedimentos para a definição dos conteúdos do ensino religioso" e estabelecimento das "normas para a habilitação e admissão dos professores". Desta modificação, pode-se inferir que a prestação do ensino religioso caracteriza-se como um ônus ao poder público, traduzindo-se, assim, numa obrigação de oferta do ensino religioso por parte do Estado. Dessa forma, a leitura do art. $208, \S 2^{\circ}$, da Constituição nos leva a crer que o não oferecimento do ensino religioso pode resultar em responsabilização da autoridade competente ${ }^{106}$.

O tema voltou à discussão pública após a assinatura, em novembro de 2009 , do “Acordo Entre a República Federativa do Brasil e a Santa Sé Relativo ao Estatuto Jurídico da Igreja Católica no Brasil”, promulgado pelo Presidente da República através do Decreto $\mathrm{n}^{\mathrm{o}} 7.107 / 2010$. O acordo, em seu art. $11, \S 1^{\circ}$, prevê que "o ensino religioso, católico e de outras confissões religiosas, de matrícula facultativa, constitui disciplina dos horários normais das escolas públicas de ensino fundamental (...)”.

Tal dispositivo, juntamente com o art. 33 da LDB, é objeto da Ação Direta de Inconstitucionalidade $\mathrm{n}^{\circ} 4439 / \mathrm{DF}^{107}$, proposta pela Procuradoria-Geral da República em agosto de 2010. A PGR propõe, em sua petição inicial, a interpretação conforme a

\footnotetext{
${ }^{105}$ WEINGARTNER NETO, Jayme. op. Cit., p. 253-4.

${ }^{106}$ Nesse sentido, v. PÊCEGO, Daniel. op. Cit., p. 82.

107 Antes mesmo, o chamado "Estatuto Jurídico da Igreja Católica no Brasil" já fora alvo da ADIn 4319/DF, ajuizada pela Convenção de Ministros das Assembleias de Deus Unidas do Estado do Ceará (Comaduec) e não conhecida pelo relator, Min. Joaquim Barbosa, ante a ausência de legitimidade ativa da proponente.
} 
Constituição dos referidos artigos, para assentar que o ensino religioso em escolas públicas só possa ser de natureza não-confessional, ou, na eventualidade, que seja declarada a inconstitucionalidade do trecho "católico e de outras confissões religiosas" do art. $11, \S 1^{\circ}$ do Acordo Brasil-Santa Sé ${ }^{108}$.

Em conclusão a essas considerações feitas sobre a Constituição de 1988, pode-se afirmar que o modelo de relação com o religioso adotado pelo Brasil está próximo do modelo de cooperação e divisão a que aludimos anteriormente, trazendo disposições muito semelhantes as da Lei Fundamental de Bonn. Com efeito, a Constituição não se mostra alheia perante qualquer culto religioso, buscando consagrar a liberdade de exercício de culto e garantindo condições para que este se efetive. De um lado, não impõe a ninguém o dever de seguir uma crença religiosa. Por outro, reconhece que a religião é elemento relevante das escolhas pessoais e íntimas de muitos dos seus cidadãos, garantindo, portanto, que esta tem uma função na vida em sociedade. Em síntese, portanto, o Estado brasileiro adota uma postura de laicidade perante a religião, reconhecendo o papel desta na vida dos indivíduos e da sua dimensão pública ${ }^{109}$.

\section{REFERÊNCIAS BIBLIOGRÁFICAS}

ADAMSON, Barry. Freedom of religion, the First Amendment, and the Supreme Court: how the Court flunked history. Gretna: Pelican Publishing Company, 2008.

BARROSO, Luís Roberto. Legitimidade da recusa de transfusão de sangue por testemunhas de jeová. Dignidade humana, liberdade religiosa e escolhas existenciais. Disponível em: <http://www.luisrobertobarroso.com.br/wpcontent/themes/LRB/pdf/testemunhas_de_jeova.pdf $>$.

. O direito constitucional e a efetividade de suas normas. Rio de Janeiro: Renovar, 2006.

\footnotetext{
108 Até o fechamento do presente estudo, nenhuma decisão, mesmo em caráter liminar, havia sido proferida no âmbito da ADIn 4439/DF, cuja relatoria foi distribuída ao Min. Ayres Britto.

109 No mesmo sentido, BARROSO, Luís Roberto. Legitimidade da recusa de transfusão de sangue por testemunhas de jeová. Dignidade humana, liberdade religiosa e escolhas existenciais, p.27. Disponível em: $<$ http://www.luisrobertobarroso.com.br/wp-content/themes/LRB/pdf/testemunhas_de_jeova.pdf>. Acesso em: 27.ago.2010.
} 
BOBBIO, Norberto. A era dos direitos. Rio de Janeiro: Campos, 1992.

BODIN DE MORAES, Maria Celina (Org.). Princípios do direito civil contemporâneo. Rio de Janeiro: Renovar, 2006.

BRUGGER, Winfried; KARAYANNI, Michael (Eds.). Religion in the public sphere: a comparative analysis of German, Israeli, American and International Law. Heidelberg: Springer, 2007.

BUZANELlO, José Carlos. Direito de resistência constitucional. $2^{\mathrm{a}}$ ed. Rio de Janeiro: Lúmen Júris, 2006.

WITTLE JR. John; VAN DER VYVAN, Johan D. (Eds.). Religious Human Rights in global perspective: legal perspectives. Cambridge: Kluwer Law International, 1996.

GASPARINI, Diógenes. Objeção de consciência e serviço policial militar. Revista Trimestral de Direito Público. São Paulo, n. 10, 1995.

GODOY, Arnaldo Moraes. A liberdade religiosa nas constituições do Brasil. Revista de Direito Constitucional e Internacional. São Paulo, n. 34, 2001.

LEVY, Leonard Williams. The Establishment Clause: religion and the First Amendment. $2^{\mathrm{a}}$ ed. Chapel Hill: University of North Carolina Press, 1994.

LOCKE, John. Carta sobre a tolerância. São Paulo: Hedra, 2007.

MENDES, Gilmar Ferreira. COELHO, Inocêncio Mártires. BRANCO, Paulo Gustavo Gonet. Curso de direito constitucional. São Paulo: Saraiva, 2009.

PÊCEGO, Daniel. Da educação religiosa em escolas públicas, 2007. Dissertação (Mestrado em Direito Público) - Universidade do Estado do Rio de Janeiro, mimeografado.

PEIXINHO, Manoel Messias; GUERRA, Isabela Franco, NASCIMENTO FILHO, Firly (Orgs.). Os princípios da Constituição de 1988: Rio de Janeiro: Lúmen Juris, 2006.

PONTES DE MIRANDA, Franciso C. Comentários à Constituição de 1967. Tomo V. São Paulo: Revista dos Tribunais, 1974. 
RAMOS, André de Carvalho. Teoria geral dos direitos humanos na ordem internacional. São Paulo: Renovar, 2005.

SARLET, Ingo Wolfgang. A eficácia dos direitos fundamentais. 4 ed. rev. atual. e ampl. Porto Alegre: Livraria do Advogado, 2004.

SCAMPINI, José. A liberdade religiosa nas Constituições brasileiras. Primeira Parte. Revista de Informação Legislativa. Brasília, n. 41, 1974.

. A liberdade religiosa nas Constituições brasileiras. Segunda Parte. Revista de Informação Legislativa. Brasília, n. 42, 1974.

. A liberdade religiosa nas Constituições brasileiras. Terceira Parte. Revista de Informação Legislativa. Brasília, n. 43, 1974.

A liberdade religiosa nas Constituições brasileiras. Quarta Parte. Revista de Informação Legislativa. Brasília, n. 44, 1974.

SCHWARTZMAN, Simon. A política da Igreja e a educação: o sentido de um pacto. Religião $\quad$ Sociedade, n. 13, 1986. Disponível em: <http://www.schwartzman.org.br/simon/alceu.htm >. Acesso em: 16.out.2009.

SILVA, José Afonso da. Comentário contextual à Constituição. São Paulo: Malheiros, 2005.

TOULOUSE, Mark G. God in Public: four ways American christianity and public life relate. Louisville: Westminster John Knox Press, 2006.

TRIBE, Lawrence H. American Constitutional Law, $2^{\mathrm{a}}$ ed. Mineola: The Foundation Press, 1988.

WEINGARTNER NETO, Jayme. Liberdade religiosa na Constituição. Porto Alegre: Livraria do Advogado, 2007. 